Review Article

\title{
Phytochemistry and Pharmacology of the Genus Equisetum (Equisetaceae): A Narrative Review of the Species with Therapeutic Potential for Kidney Diseases
}

\author{
Thaise Boeing $\left(\mathbb{D},{ }^{1}\right.$ Karyne Garcia Tafarelo Moreno $\mathbb{D}^{\mathbb{D}},{ }^{2}$ Arquimedes Gasparotto Junior $\mathbb{D}^{2},{ }^{2}$ \\ Luisa Mota da Silva $\unrhd^{3},{ }^{3}$ and Priscila de Souza $\oplus^{3}$ \\ ${ }^{1}$ Escola de Ciências Farmacêuticas de Ribeirão Preto, Universidade de São Paulo, Ribeirão Preto, São Paulo, Brazil \\ ${ }^{2}$ Laboratório de Farmacologia Cardiovascular (LaFaC), Faculdade de Ciências da Saúde, \\ Universidade Federal da Grande Dourados, Dourados, MS, Brazil \\ ${ }^{3}$ Programa de Pós-Graduação em Ciências Farmacêuticas, Núcleo de Investigações Químico-Farmacêuticas, \\ Universidade do Vale do Itajaí, Itajaí, Brazil \\ Correspondence should be addressed to Thaise Boeing; tize.thaise@gmail.com and Priscila de Souza; \\ priscilasouza_rc@yahoo.com.br
}

Received 20 October 2020; Revised 11 January 2021; Accepted 15 January 2021; Published 5 March 2021

Academic Editor: Sebastian Granica

Copyright (C) 2021 Thaise Boeing et al. This is an open access article distributed under the Creative Commons Attribution License, which permits unrestricted use, distribution, and reproduction in any medium, provided the original work is properly cited.

The Equisetum genus, Equisetaceae family, is widely distributed worldwide and may be the oldest nonextinct genus on Earth. There are about 30 known species, which are very often used in traditional medicine with diverse applications. This review aimed to compile scientific reports about Equisetum species with relevant pharmacological properties and/or therapeutic potential for kidney diseases. Our bibliographic survey demonstrates that the most widespread traditional use of Equisetum is as a diuretic, followed by the treatment of genitourinary diseases (kidney diseases, urethritis, kidney stones, and others), inflammation, wound healing, rheumatic diseases, prostatitis, and hypertension. The most popular species from the Equisetum genus with medicinal use is E. arvense L., whose diuretic effect was confirmed in animal models and clinical trials. The species E. bogotense Kunth also demonstrated the beneficial effect of inducing diuresis in both experimental and clinical assays. Several other species have also been studied regarding their therapeutic potential, showing different biological actions. Regarding the chemical composition, it contains many active constituents, such as alkaloids, flavonoids, phenol, phytosterols, saponins, sterols, silicic acid, tannin, triterpenoids, and volatile oils. However, despite the widespread traditional use, many species need to be explored in detail for scientific validation of popular use. Indeed, the species of the Equisetum genus have great potential in the management of kidney disorders.

\section{Introduction}

The genus Equisetum, belonging to the Equisetaceae family, from Equisetales order and Equisetopsida class, is a genus of perennial plants that reproduce by spores not seeds, widely distributed worldwide, only absent in Australasia and Antarctica [1,2]. It may be the oldest nonextinct genus on Earth, originating from the end of the Paleozoic era, about 300 million years ago. There are about 30 known species, with the majority consisting of small plants, which rarely reach a meter in height. Its varied species are adapted to grow in temperate, tropical, and cold regions. They are often used in traditional medicine with diverse applications in many countries, having mainly anti-inflammatory and diuretic activities [3].

The species of Equisetum genus are known by the common name of "horsetail" in English-speaking countries, "cola de caballo" in Spanish-speaking countries, "prêle des champs" in France, "ackerschachtelhalm" in Germany, "tsukushi" in Japan, and "cavalinha" in Brazil. Its name is of Latin origin, composed of "equi" (horse) and "setum" (tail), that is, horse tail [4-6]. The most popular species from the 
Equisetum genus with medicinal use is E. arvense L., which has already demonstrated many biological properties, such as antioxidant, antitumoral, antimicrobial, smooth muscle relaxant, anticonvulsant, sedative, antianxiety, antinociceptive, anti-inflammatory, antidiabetic, diuretic, platelet aggregation inhibitory, osteoblastic response promoting, and antileishmanial effects (for review see [7]). However, many other species are also known for their popular usage and common indications for diuretic purposes and kidney disorders, as will be addressed in this review.

For that, this review's objective was to compile the data found in the literature about Equisetum species with relevant pharmacological properties for the treatment of kidney disorders, especially associated with arterial hypertension. We have collected reports from ethno botanical textbooks, and scientific articles from books and journals indexed online in the databases PubMed (https://www.ncbi.nlm.nih. gov/pubmed), Science Direct (http://www.sciencedirect. $\mathrm{com} /$ ), and Medline (https://www.nlm.nih.gov/bsd/ pmresources.html). We will discuss popular uses, toxicological data, phytochemical composition, and pharmacological evidence of these species in the next topics. The main findings are summarized in tables for each theme.

\section{Traditional Applications and Toxicological Information}

Studies that describe this genus's traditional applications, summarized in Table 1, show that the oral administration is the most common route for its use, using the infusion or decoction of the aerial parts as the main method of preparation $[1,9,42]$. The most widespread traditional use of Equisetum is as a diuretic [1, 12, 33, 34, 41, 42], followed by the treatment of genitourinary diseases (kidney diseases, urethritis, kidney stones, and others) $[10,16,25$, $26,33,34,37-39]$, inflammation [10, 20-22, 27, 40], wound healing $[21,28,39,41]$, rheumatic diseases $[9,19,31,34,39]$, prostatitis [33, 36, 40], and hypertension [1, 21, 27].

Studies compiled in this work pointed out that the most popular species from the Equisetum genus with medicinal use is E. arvense L., commonly known as "horsetail", with uses reported in countries like Brazil, Romania, Germany, Serbia, China, Greece, Portugal, Iran, and Thailand. This species is used mainly as diuretic, to treat inflammation, genitourinary diseases, ulcers, wound healing, dermatitis, hemorrhage, hepatitis, prostatitis, musculoskeletal diseases, and others (Table 1) [12, 20-22, 25, 33, 38, 39, 41, 42]. Nevertheless, Baracho et al. [43] evaluated the acute hepatotoxicity of $E$. arvense in rats. The extract at 30, 50, and $100 \mathrm{mg} / \mathrm{kg}$ did not show mortality in any of the doses at the end of the 14 days of observation, nor did it alter the serum activities of hepatic enzymes compared to the control group. Instead, it produced benign changes in the hepatic morphology. Moreover, Tago et al. [44] evaluated the toxicity of $E$. arvense in the diet at doses of $0,0.3,1$, and $3 \%$ for 13 weeks in male and female rats. According to the authors, the dosage selections were based on estimated intake for humans, approximately $5 \mathrm{mg} / \mathrm{kg}$ daily. No toxicity was detected related to clinical signs, body weight, urinalysis, hematology, serum biochemistry data, organ weights, and histopathological findings. Still, remedies containing E. arvense are not recommended during pregnancy or breastfeeding since little information is available on their safety [45]. Indeed, the species contains thiaminase, an enzyme that destroys thiamine (vitamin B1), and, with long-term use, could lead to vitamin deficiency, a possible cause of neurotoxicity [46].

Another well-cited species is E. telmateia Ehrh., known as "great horsetail" [47], used to treat rheumatism, broken bones, genitourinary diseases, prostatitis, gastrointestinal disorders, inflammation, and hypertension, in addition to its use as diuretic and expectorant in countries like Turkey, Portugal, Iran, and Spain [1, 34, 36, 37, 40]. However, little information is available about its safety. E. giganteum L., commonly called "giant horsetail" [10], is another widespread species mainly in Latin American countries like Brazil, Bolivia, Chile, and Peru, traditionally used to treat diarrhea, heartburn, genitourinary disorders, inflammation, rheumatic diseases, obesity, and as a diuretic [8-11, 18, 28]. Despite its widespread traditional use, no in vivo toxicity studies were conducted so far; however, Alavarce et al. [10] showed no cytotoxic potential of the hydroalcoholic extract of E. giganteum aerial parts $(50,25,16,8$, and $4 \mathrm{mg} / \mathrm{mL})$ on human palatal epithelial cells and human monocytes using MTT assay.

Similarly to E. giganteum, the species Equisetum bogotense Kunth also grows in Chile, where it is widely used in traditional medicine as a diuretic [48]. As far as we know, there are no cytotoxic studies carried out on animals with this species; however, E. bogotense was subjected to a clinical study where 25 healthy patients received their infusion at an equivalent dose of $0.75 \mathrm{~g}$ of the plant per person, daily, for two consecutive days, but no adverse reactions were detected (e.g., diarrhea, asthenia, dizziness, colic, vomiting, palpitations, and hypotension) [18].

Equisetum myriochaetum Schlecht. and Cham. is a plant distributed in Mexico, where it is popularly known as "cola de caballo" [49] and traditionally used for the treatment of diabetes type 2 and kidney disease [14-17]. Regarding toxicological information, Téllez et al. [49] have shown that extracts from E. myriochaetum aerial parts had no acute toxicity detected in Drosophila or in the human micronucleus test in vitro performed with cultured lymphocytes, emphasizing that this species is not genotoxic.

Moreover, Equisetum debile Roxb. ex Vaucher, also known as "horsetail", is widely distributed throughout Thailand. The local population has been used as a diuretic, wound muscle relaxant, hair growth stimulant, and anti-hair loss treatment. The E. debile extracts showed no cytotoxicity on dermal papilla cell line ( 1 to $500 \mu \mathrm{g} / \mathrm{mL}$ ) and no irritation on chorioallantoic membrane of hen's eggs (0.5\%) [41], but further studies are needed to ensure their safety.

Equisetum palustre L., known as "marsh horsetail" [50], has been traditionally used in Turkey for peptic ulcer, hemorrhoids, and kidney stones treatment [35]. Despite this, E. palustre has been known for its toxicity for livestock, which is related to the presence of thiaminase and the 
TABle 1: Traditional applications of Equisetum genus stratified by country, species, plant part, and medicinal use.

\begin{tabular}{|c|c|c|c|c|c|}
\hline Country & Species & Plant part & $\begin{array}{c}\text { Preparation } \\
\text { method }\end{array}$ & Medicinal use & Reference \\
\hline Bolivia & Equisetum giganteum $L$. & $\begin{array}{l}\text { Stem, entire } \\
\text { plant }\end{array}$ & Decoction & $\begin{array}{c}\text { Diarrhea, stomach heat, liver and kidneys diseases, } \\
\text { inflammation }\end{array}$ & {$[8]$} \\
\hline \multirow[t]{2}{*}{ Brazil } & Equisetum giganteum $L$. & $\begin{array}{l}\text { Stems } \\
\text { parts }^{\mathrm{b}}\end{array}$ & $\begin{array}{l}\text { Decoction, } \\
\text { infusion }^{\mathrm{a}}\end{array}$ & $\begin{array}{c}\text { Rheumatic diseases } \\
\text { Diuretic, urinary disorders, inflammation } \\
\text { Weight loss }{ }^{\mathrm{c}}\end{array}$ & $\begin{array}{l}{[9]^{\mathrm{a}}} \\
{[10]^{\mathrm{b}}} \\
{[11]^{\mathrm{c}}}\end{array}$ \\
\hline & Equisetum arvense $\mathrm{L}$. & Aerial parts & Infusion $^{\mathrm{a}}$ & $\begin{array}{c}\text { Diuretic }^{\mathrm{ab}} \\
\text { Remineralization, inflammation }^{\mathrm{b}}\end{array}$ & {$[12]^{\mathrm{a}}$} \\
\hline Mexico & $\begin{array}{l}\text { Equisetum myriochaetum } \\
\text { Schlecht and Cham }\end{array}$ & Aerial parts & Infusion $^{\mathrm{ab}}$ & $\begin{array}{l}\text { Diabetes type } 2^{\mathrm{abc}} \\
\text { Kidney diseases, diabetes }\end{array}$ & $\begin{array}{l}{[15]^{\mathrm{b}}} \\
{[16]^{\mathrm{c}}} \\
{[17]^{\mathrm{d}}}\end{array}$ \\
\hline Chile & $\begin{array}{l}\text { Equisetum bogotense Kunth } \\
\text { Equisetum giganteum L. } \\
\text { Equisetum arvense L. }\end{array}$ & Aerial parts & Infusion & Diuretic & {$[18]$} \\
\hline Lebanon & $\begin{array}{c}\text { Equisetum maximum } \\
\text { Lam.Equisetum telmateia } \\
\text { Ehrh. }\end{array}$ & Aerial parts & Decoction & Antirheumatic, antineuralgic & {$[19]$} \\
\hline Romania & Equisetum arvense $\mathrm{L}$. & $\begin{array}{l}\text { Sterile aerial, } \\
\text { stems }\end{array}$ & Unreported & $\begin{array}{l}\text { Inflammation }^{\mathrm{ab}} \\
\text { Ulcers, skin tumors, itching, wound healing, bruise, } \\
\text { chilblains, leukorrhea, paronychia, foot hyperhidrosis, } \\
\text { impetigo, furuncle, dermatitis, neurodermatitis }\end{array}$ & $\begin{array}{l}{[20]^{\mathrm{a}}} \\
{[21]^{\mathrm{b}}}\end{array}$ \\
\hline Germany & Equisetum arvense $\mathrm{L}$. & Aerial parts & Unreported & Inflammation & {$[22]$} \\
\hline Serbia & Equisetum arvense $\mathrm{L}$. & $\begin{array}{l}\text { Whole plant } \mathrm{t}^{\mathrm{a}} \text {, } \\
\text { sterile stems } \mathrm{s}^{\mathrm{b}}\end{array}$ & Infusion & $\begin{array}{c}\text { Urogenital diseases, diuretic }{ }^{\mathrm{a}} \\
\text { Kidney diseases, arthritis, bleeding ulcers, tuberculosis, } \\
\text { wounds healing }{ }^{\mathrm{b}}\end{array}$ & $\begin{array}{l}{[23]^{\mathrm{a}}} \\
{[24]^{\mathrm{b}}}\end{array}$ \\
\hline China & $\begin{array}{l}\text { Equisetum arvense } \mathrm{L} . \\
\text { Equisetum hyemale } \mathrm{L} . \\
\text { Equisetum ramosissimum } \\
\text { Desf. }\end{array}$ & $\begin{array}{l}\text { Aerial parts } \\
\text { Aerial parts } \\
\text { Aerial parts }\end{array}$ & $\begin{array}{l}\text { Unreported } \\
\text { Unreported } \\
\text { Unreported }\end{array}$ & $\begin{array}{c}\text { Hemorrhage, urethritis, jaundice, hepatitis } \\
\text { Hypertension, inflammation, acute stroke, bleeding, } \\
\text { cancer } \\
\text { Hemorrhage, urethritis, jaundice, hepatitis }\end{array}$ & {$[25-27]$} \\
\hline Peru & Equisetum giganteum $\mathrm{L}$. & Aerial parts & Unreported & Diarrhea, diuretic, emmenagogue, wound healing & [28] \\
\hline Colombia & Equisetum bogotense Kunth & Wh & $\begin{array}{l}\text { Infusion, } \\
\text { decoction }\end{array}$ & Diuretic, kidney stones & {$[29]$} \\
\hline India & Equisetum arvense $\mathrm{L}$. & Aerial parts & Infusion & Strengthen bones, hair, nails & {$[30]$} \\
\hline Italy & Equisetum arvense $\mathrm{L}$. & $\begin{array}{l}\text { Dried } \\
\text { sterile } \\
\text { stems }\end{array}$ & Infusion & $\begin{array}{l}\text { Remineralizing, diuretic, inflammation, rheumatoid } \\
\text { arthritis }\end{array}$ & {$[31]$} \\
\hline Croatia & Equisetum arvense $\mathrm{L}$. & Aerial parts & Infusion & Diabetes & {$[32]$} \\
\hline Greece & Equisetum arvense $\mathrm{L}$. & Aerial parts & Decoction & $\begin{array}{c}\text { Urogenital disorders, prostatitis, diuretic, } \\
\text { musculoskeletal diseases }\end{array}$ & {$[33]$} \\
\hline Turkey & $\begin{array}{l}\text { Equisetum telmateia Ehrh. } \\
\text { Equisetum palustre L. }\end{array}$ & $\begin{array}{l}\text { Aerial parts } \\
\text { Aerial parts }\end{array}$ & $\begin{array}{l}\text { Decoction } \\
\text { Infusion }\end{array}$ & $\begin{array}{l}\text { Acne, rheumatism, broken bones, diuretic, } \\
\text { expectorant, kidney stones, strengthening hair, skin, } \\
\text { and nails } \\
\text { Peptic ulcer, hemorrhoids, kidney stones }\end{array}$ & {$[34,35]$} \\
\hline Portugal & $\begin{array}{l}\text { Equisetum telmateia Ehrh. } \\
\text { Equisetum arvense L. }\end{array}$ & $\begin{array}{l}\text { Aerial parts } \\
\text { Aerial parts }\end{array}$ & $\begin{array}{l}\text { Unreported } \\
\text { Unreported }\end{array}$ & $\begin{array}{l}\text { Prostatitis, stomachaches, and cystitis }{ }^{\mathrm{a}} \\
\text { Urinary, kidney, gastrointestinal disorders } \\
\text { Arthritis, kidney diseases, bleeding ulcers, hepatitis, } \\
\text { jaundice, and tuberculosis }\end{array}$ & $\begin{array}{l}{[36]^{\mathrm{a}}} \\
{[37]^{\mathrm{b}}} \\
{[38]}\end{array}$ \\
\hline Iran & $\begin{array}{l}\text { Equisetum arvense } \mathrm{L} . \\
\text { Equisetum telmateia Ehrh. }\end{array}$ & $\begin{array}{l}\text { Aerial parts } \\
\text { Aerial parts }\end{array}$ & $\begin{array}{l}\text { Unreported } \\
\text { Unreported }\end{array}$ & $\begin{array}{l}\text { Wound healing, strengthening of the bones, teeth, } \\
\text { nails, and hair, gout, nosebleeds, urinary and prostate } \\
\text { disorders, menorrhagia, rheumatoid arthritis } \\
\text { Prostatitis, stomachache, inflammation, diarrhea, } \\
\text { mouth infections, chronic eczema, antifungal }\end{array}$ & {$[39,40]$} \\
\hline Thailand & $\begin{array}{l}\text { Equisetum arvense } \mathrm{L} . \\
\text { Equisetum debile Roxb. ex } \\
\text { Vaucher }\end{array}$ & $\begin{array}{l}\text { Aerial parts } \\
\text { Aerial parts }\end{array}$ & $\begin{array}{l}\text { Unreported } \\
\text { Unreported }\end{array}$ & $\begin{array}{c}\text { Hair loss } \\
\text { Diuretic, wound healing, muscle relaxant, hair growth } \\
\text { stimulant, hair loss }\end{array}$ & [41] \\
\hline Spain & $\begin{array}{l}\text { Equisetum telmateia Ehrh. } \\
\text { Equisetum arvense L. } \\
\text { Equisetum ramosissimum } \\
\text { Desf. }\end{array}$ & $\begin{array}{l}\text { Aerial parts } \\
\text { Aerial parts } \\
\text { Aerial parts }\end{array}$ & $\begin{array}{l}\text { Infusion }^{\mathrm{ab}} \\
\text { Decoction, }^{\mathrm{a}} \\
\text { infusion }^{\mathrm{ab}} \\
\text { Infusion }^{\mathrm{a}}\end{array}$ & $\begin{array}{c}\text { Hypertension, diuretic }{ }^{\mathrm{a}} \\
\text { Bones disorders, to strengthen broken bones } \\
\text { Hypertension, diuretic } \\
\text { Bone disorders, to strengthen broken bones } \\
\text { Depurative, diuretic }\end{array}$ & $\begin{array}{c}{[1]^{\mathrm{a}}} \\
{[42]^{\mathrm{b}}}\end{array}$ \\
\hline
\end{tabular}

Equal letters in the same line relate plant part, preparation method, and medicinal use to respective studies (column of references). 
alkaloids palustrine and nicotine [50]. Besides, Milovanović et al. [24] showed that E. palustre, as well as E. arvense L., E. sylvaticum L., E. fluviatile L., and E. telmateia Ehrh. extracts $(62.5 \mu \mathrm{g} / \mathrm{ml})$, showed some genotoxicity, presenting a higher incidence of micronucleus formation than that of the control.

\section{Phytochemistry Data of Equisetum Genus}

In this topic, we reviewed the phytochemistry data available on the plants' species of Equisetum genus (Table 2), which have already been presented for their traditional applications. Chemical structures of the compounds identified in the Equisetum genus followed by their names, molecular weights, and references are shown in Figure S1 (Supplementary Material).

E. arvense L. contains various chemical compounds such as silicic acid, linoleic acid, oleic acid, stearic acid, linolenic acid and traces of alkaloids (e.g., equisetin, nicotine, palustrine, and palustrinine), glucoside, flavonoids, saponosides, triterpenoids, phytosterols, calcium carbonate, potassium sulfate, potassium chloride, manganese chloride, iron, manganese, and calcium phosphate $[39,52]$. Indeed, Veit et al. [51] isolated two styrylpyrone glucosides ( $3^{\prime}$ deoxyequisetumpyrone and $4^{\prime}$-O-methylequisetumpyrone) from the $\mathrm{MeOH}$ extract from the rhizomes of $E$. arvense. Besides, in the hepatoprotective activity-guided fractionation of the $\mathrm{MeOH}$ extract from the aerial parts of E. arvense L. performed by Oh et al. [25], the bioactive EtOAc fraction was subjected to octadecyl-functionalized silica gel flash column chromatography resulting in the isolation of two phenolic petrosins (onitin and onitin-9-O-glucoside) and four flavonoids (apigenin, luteolin, kaempferol-3-O-glucoside, and quercetin-3-O-glucoside). Similarly, MimicaDuki [52] evaluated the phenolic composition of three different extracts (EtOAc, $\mathrm{n}-\mathrm{BuOH}$, and $\mathrm{H}_{2} \mathrm{O}$ ). In this study, quercetin 3-O-glucoside (isoquercitrin) was the main compound in the EtOAc identified by high-performance liquid chromatography with diode-array detection (HPLC$\mathrm{DAD})$. At the same time, apigenin 5-O-glucoside and kaempferol 3-O-glycoside were detected in considerable amounts. The $\mathrm{n}-\mathrm{BuOH}$ extract showed higher amounts of isoquercitrin and di-E-caffeoyl-meso-tartaric acid, while the aqueous extract had di-E-caffeoyl-meso-tartaric acid and also two phenolic acids detected. Also, Ganeva et al. [53] isolated terpenoids (taraxerol, $\beta$-amyrin, germanicol, $\alpha$-amyrin, ursolic acid, oleanolic acid, betulinic acid, taraxasterone, and $\psi$-taraxasterone) and some sterols (isobauerenol, epicholestanol, cholesterol, sitosterol, and 28-isofucosterol) from the aerial parts of this species using preparative thin layer chromatography (PTLC) and gas chromatography-mass spectrometry (GC-MS). In this sense, Fons et al. [55] investigated the volatile profile of fresh aerial parts of E. arvense, also using GC-MS. The plant contained a great biodiversity of isoprenoid flavor precursors (3-hydroxy-7,8-epoxy- $\beta$-ionol, $(E, E)$-pseudoionone, and 3 -oxo- $\alpha$-ionol), as well as odorous benzenic derivatives (phenylethanal, 2-phenylethanol, benzaldehyde, and homovanillic acid).
The hydroalcoholic extract of E. arvense sterile stems was also characterized by Milovanović et al. [24]. The authors have found the nonmalonylated quercetin 3-O-glucoside and the free aglycone quercetin as the major constituents, but quercetin 3-O-(6"-O-malonylglucoside), 5-O-caffeoyl shikimic acid, monocaffeoyl-meso-tartaric acid, and dicaffeoyl-meso-tartaric acid were also detected. Besides, Gründemann et al. [22] have also focused on the E. arvense extract's phytochemical analysis on identifying flavonoids and other polar phenolics. A decoction produced by boiling a part of dry plant material with nine parts of ethanol for $4 \mathrm{~h}$ was subjected to the HPLC method to separate the phenolic compounds in the extract later identified by liquid chromatography-mass spectrometry (LC-MS). The major constituents were mono-, di-, and triglycosides of kaempferol, quercetin, apigenin, genkwanin, and protogenkwanin well as mono- and dicaffeoyl-tartaric acid. Besides, three phenolic glycosides, equisetumoside $\mathrm{A}$, equisetumoside $\mathrm{B}$, and equisetumoside $C$, were isolated from the water-soluble extract of fertile sprouts of E. arvense L., together with uridine, inosine, $2^{\prime}$-deoxyinosine, $2^{\prime}$-deoxycytidine, tryptophan, thymidine, 5-carboxy- $2^{\prime}$-deoxyuridine, coniferin, and kaempferol 3-O- $\beta$-D-sophoroside-7-O- $\beta$-D-glucopyranoside, by Chang et al. [54].

As described in the clinical study conducted by Lemus et al. [18], only a few chemical screenings have been published in the late 1980s and early 1990s demonstrating the presence of $\beta$-sitosterol, silicic anhydride, flavonoids, and coumarins, as well as isokaemferide and kaempferol derivatives in E. bogotense HBK. Besides, more recently, Tipke et al. [56] identified and quantified the alkaloids present in this species by hydrophilic interaction liquid chromatography high-performance liquid chromatography tandem mass spectrometry (HILIC HPLC-MS/MS) in electrospray ionization (ESI). The plant material was powdered using a standard electric coffee grinder and submitted to alkaloids extraction using sulphuric acid. The presence of nicotine, palustrine, and palustridiene was detected; however, only two out of five samples were positive for the compounds. Therefore, the authors stated that more data is necessary to have a clearer picture of the occurrence of alkaloids in this species.

$\mathrm{Xu}$ et al. [58] reported the isolation and characterization of three new megastigmane glucosides and four known constituents from the whole plant of E. debile. The dried whole plant of E. debile was extracted with $\mathrm{CHCl}_{3}$ and $70 \% \mathrm{EtOH}$. After solvent evaporation, the EtOH extract was partitioned with $\mathrm{AcOEt}$ and $\mathrm{BuOH}$, subjected to column chromatography (CC). The AcOEt fraction afforded blumenol A and corchoinoside $\mathrm{C}$, while $\mathrm{BuOH}$-soluble extract afforded sammangaoside $\mathrm{A}$, debilosides $\mathrm{A}-\mathrm{C}$, and (3S,5R,6R,7E,9S)-9-[( $\beta-\mathrm{D}-$ glucopyranosyl)oxy]megastigm-7-ene-3,5,6-triol. Moreover, Tan et al. [57] investigated this plant's chemical constituents obtaining 12 compounds. The whole dried plant of E. debile was powdered, extracted with EtOH, and posteriorly partitioned. The EtOAc fraction yielded the new phenylhexane debilitriol, the new alkaloid equisetumine, guaiacylglycerol$\beta$-coniferyl ether, and the compounds 5-hydroxymethyl-2furfuraldehyde, coumaric acid, $p$-hydroxybenzoic acid, and 
TABle 2: Phytochemistry of Equisetum genus stratified by species, plant part, method, and compounds.

\begin{tabular}{|c|c|c|c|c|}
\hline Species & Plant part & Extract/method & Compounds & Reference \\
\hline & Rhizomes & $\mathrm{MeOH} / \mathrm{CC}-\mathrm{HPLC}$ & $\begin{array}{c}3^{\prime} \text {-Deoxyequisetumpyrone } \\
4^{\prime} \text {-O-Methylequisetumpyrone }\end{array}$ & [51] \\
\hline & & & Onitin & \\
\hline & & & Onitin-9-O-glucoside & \\
\hline & & EtOAc fraction/CC & $\begin{array}{l}\text { Apigenin } \\
\text { Luteolin }\end{array}$ & [25] \\
\hline & & & Kaempferol 3-O-glucoside & \\
\hline & & & Quercetin 3-O-glucoside & \\
\hline & & & Quercetin 3-O-glucoside & \\
\hline & & EtOAc fraction/HPLC-DAD & Apigenin 5-O-glucoside & \\
\hline & & & Kaempferol 3-O-glycoside & \\
\hline & & n-BuOH fraction/HPLC-DAD & $\begin{array}{c}\text { Quercetin 3-O-glucoside } \\
\text { Di- } E \text {-caffeoyl-meso-tartaric acid }\end{array}$ & [52] \\
\hline & & & $\begin{array}{l}\text { Di-E-carfeoyl-meso-tartaric acid } \\
\text { Di-E-caffeoyl-meso-tartaric acid }\end{array}$ & \\
\hline & & $\mathrm{H}_{2} \mathrm{O}$ fraction/HPLC-DAD & Phenolic acid 1 & \\
\hline & Aerial parts & & Phenolic acid 2 & \\
\hline & Aentar parts & & Taraxerol & \\
\hline & & & $\beta$-amyrin & \\
\hline & & & $\begin{array}{l}\text { Germanicol } \\
\alpha \text {-Amyrin }\end{array}$ & \\
\hline & & & $\begin{array}{l}\alpha \text {-Amyrin } \\
\text { Ursolic acid }\end{array}$ & \\
\hline & & & Oleanolic acid & \\
\hline & & Petrol/PTLC-GC-MS & Betulinic acid & \\
\hline & & & Isobauerenol & [53] \\
\hline & & & Epicholestanol & \\
\hline & & & Cholesterol & \\
\hline & & & Sitosterol & \\
\hline & & & 28-Isofucosterol & \\
\hline & & & Taraxasterone & \\
\hline & & & $\psi$-Taraxasterone & \\
\hline & & & $\begin{array}{c}\text { Mono-, di-, and triglycosides of kaempferol } \\
\text { Quercetin }\end{array}$ & \\
\hline & Unreported & Ethanol decoct/HPLC & Apigenin & [20] \\
\hline & Unreportea & Etnanol decoct/HPLC & Genkwanin & {$[22]$} \\
\hline & & & Protogenkwanin & \\
\hline \multirow{37}{*}{ Equisetum arvense $\mathrm{L}$. } & & & Mono- and dicaffeoyl-tartaric acid & \\
\hline & & & Equisetumoside A-C & \\
\hline & & & Uridine & \\
\hline & & & Inosine & \\
\hline & & & $2^{\prime}$-Deoxyinosine & \\
\hline & Fertile & & $2^{\prime}$-Deoxycytidine & \\
\hline & sprouts & Water-soluble/spectroscopic analysis & Tryptophan & [54] \\
\hline & & & Thymidine & \\
\hline & & & 5-Carboxy-2'-deoxyuridine & \\
\hline & & & Coniferin & \\
\hline & & & Kaempferol 3-O- $\beta$-D-sophoroside-7-O- $\beta$-D-glucopyranoside & \\
\hline & & & Quercetin & \\
\hline & & & Quercetin 3-O-glucoside & \\
\hline & & & Quercetin 3-O-(6"-O-malonylglucoside) & \\
\hline & Stems & Hydroalcoholic/HPLC & 5-O-Caffeoyl shikimic acid & [24] \\
\hline & & & Monocaffeoyl meso-tartaric acid & \\
\hline & & & Dicaffeoyl meso-tartaric acid & \\
\hline & & & Benzaldehyde & \\
\hline & & & Phenylethanal & \\
\hline & & & 2-Phenylethanol & \\
\hline & & & 4-Vinylguaiacol & \\
\hline & & & Isovanillin & \\
\hline & & & Homovanillic acid & \\
\hline & & & 2,3-Octanedione & \\
\hline & & & Hexanoic acid & \\
\hline & & & (Z)-3-Hexanoic acid & \\
\hline & & & (E)-2-Hexanoic acid & {$[55]$} \\
\hline & Aerial parts & Diethyl ether/GC-MS & Dihydroactinidiolide & [55] \\
\hline & & & (E,Z)-Pseudoionone & \\
\hline & & & $(E, E)$-Pseudoionone & \\
\hline & & & 3-Hydroxy- $\beta$-ionol & \\
\hline & & & 4-Hydroxy- $\beta$-ionol & \\
\hline & & & 3-Oxo- $\alpha$-ionol & \\
\hline & & & 3-Hydroxy-7,8-dihydro- $\beta$-ionol & \\
\hline & & & 3 -Hydroxy-7,8-epoxy- $\beta$-ionol & \\
\hline & & & 4 -Oxo- $\beta$-ionone & \\
\hline & & & 4-Hydroxy-7,8-dihydro- $\beta$-ionol & \\
\hline
\end{tabular}


TABle 2: Continued.

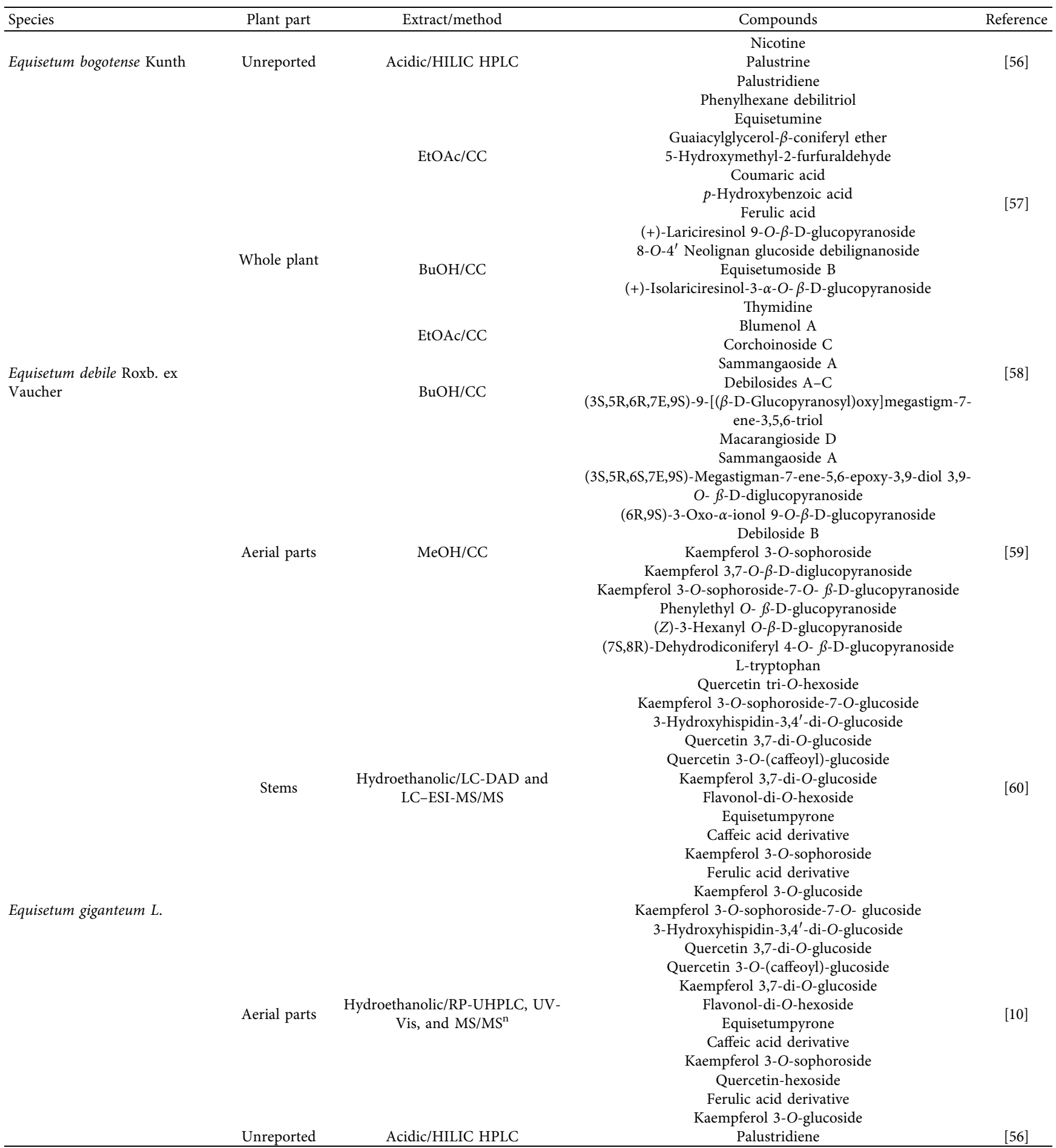


TABle 2: Continued.

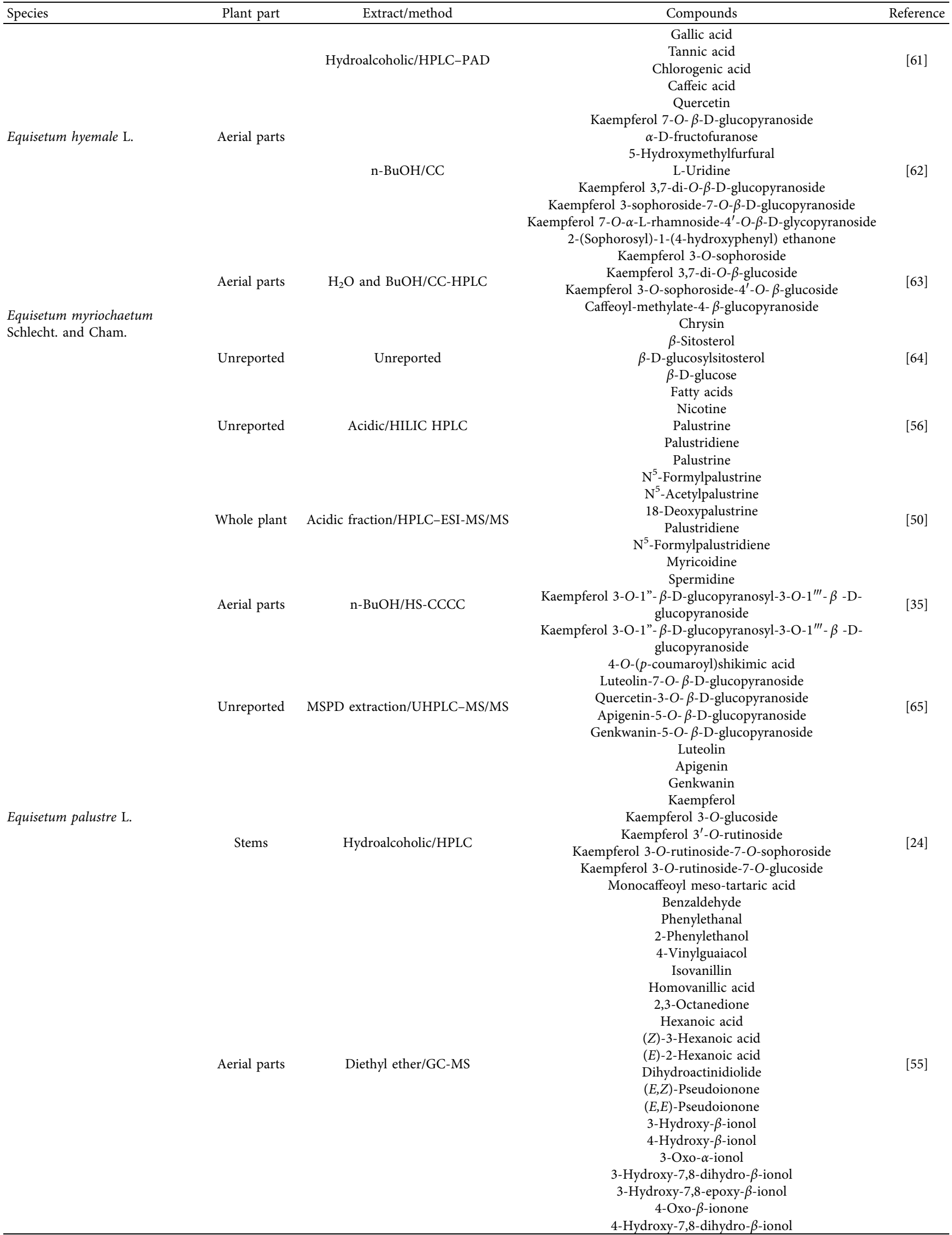


TABLE 2: Continued.

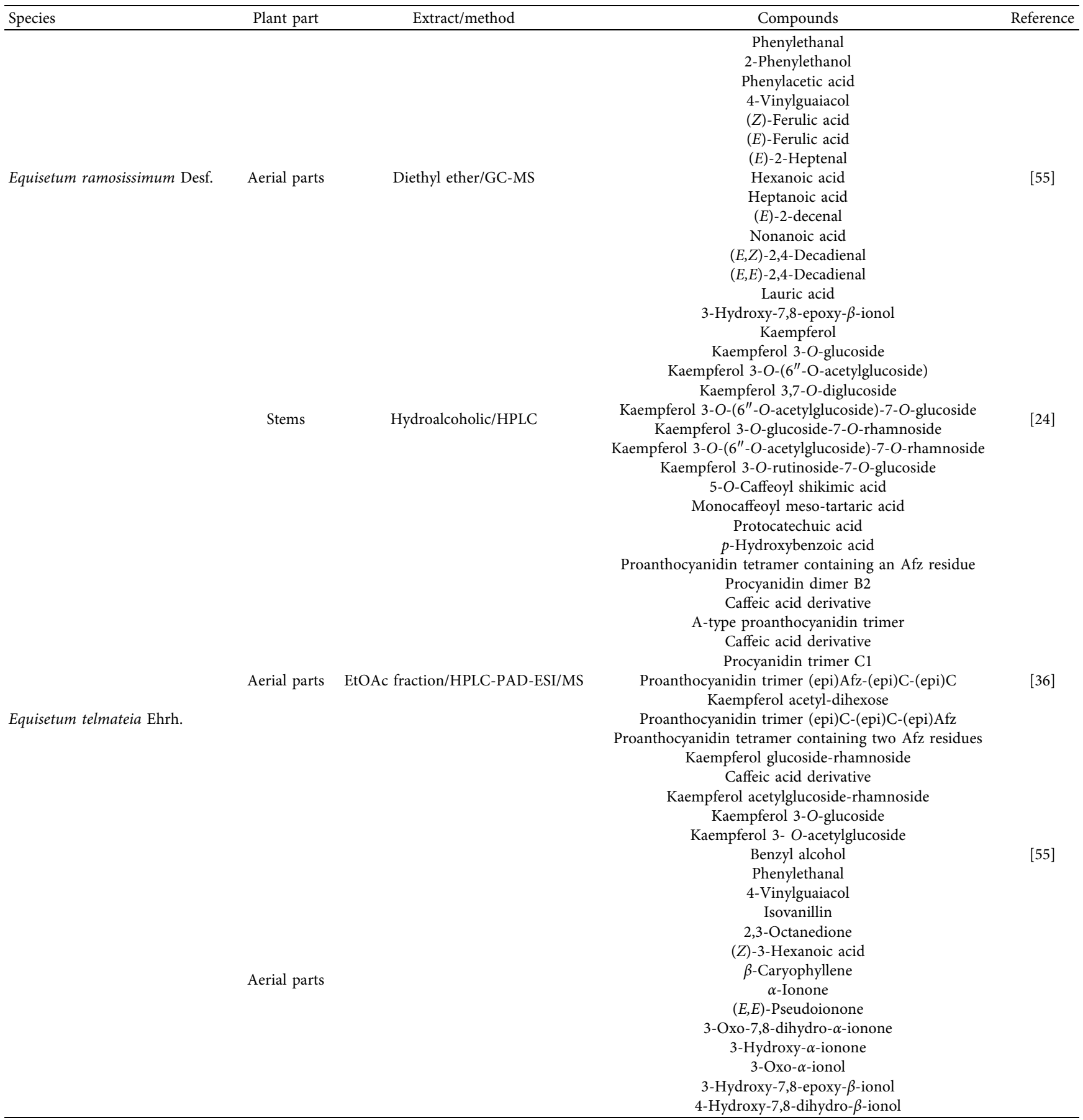

Afzelechin (Afz); column chromatography (CC); gas chromatography (GC); epicatechin or catechin ((epi)C); epiafzelechin or afzelechin ((epi)Afz); highperformance liquid chromatography (HPLC); high-speed centrifugal countercurrent chromatography (HS-CCCC); diode-array detector (DAD); hydrophilic interaction chromatography (HILIC); liquid chromatography (LC); electrospray ionization (ESI); mass spectrometry (MS); reversed-phase ultra-highperformance liquid chromatography (RP-UHPLC); pulsed amperometric detection (PAD); ultraviolet-visible spectroscopy (UV-Vis); preparative thin layer chromatography (PTLC).

ferulic acid. In contrast, the compounds (+)-lariciresinol 9-O$\beta$-D-glucopyranoside, $8-O-4^{\prime}$ neolignan glucoside debilignanoside, equisetumoside $\mathrm{B},(+)$-isolariciresinol-3a- $O-\beta$-D-glucopyranoside, and thymidine were obtained from $\mathrm{BuOH}$ fraction. Besides, Kanchanapoom et al. [59] described the isolation of chemical constituents from the $\mathrm{MeOH}$ extract from aerial parts of $E$. debile, including megastigmane glucosides (macarangioside $D$, sammangaoside $\mathrm{A},(3 \mathrm{~S}, 5 \mathrm{R}, 6 \mathrm{~S}, 7 \mathrm{E}, 9 \mathrm{~S})$ megastigman-7-ene-5,6-epoxy-3,9-diol 3,9-O- $\beta$-D-diglucopyranoside, (6R,9S)-3-oxo-a-ionol 9-O- $\beta$-D-glucopyranoside, and debiloside $\mathrm{B}$ ), flavonoid glycosides (kaempferol 3-Osophoroside, kaempferol 3,7-O- $\beta$-D-diglucopyranoside, 
kaempferol 3-O-sophoroside-7-O- $\beta$-D-glucopyranoside), a phenylethanoid glucoside (phenylethyl $O-\beta$-D-glucopyranoside), an aliphatic glucoside (Z)-3-hexenyl $O$ - $\beta$-D-glucopyranoside), a neolignan glucoside ((7S, $8 \mathrm{R})$-dehydrodiconiferyl 4-O- $\beta$-D-glucopyranoside), and amino acid (L-tryptophan).

Francescato et al. [60] have evaluated the phenolic composition of the hydroalcoholic extract of E. giganteum stems by LC-DAD and LC-ESI-MS/MS allowing the characterization of 12 compounds (Table 2). Caffeic acid derivatives, flavonoids, and styrylpyrones were detected; in addition, the phenolic components quercetin-3-O-(caffeoyl)-glucoside and 3-hydroxyhispidin-3,4'-di-O-glucoside were reported for the first time in the Equisetum genus, while the most abundant flavonoids were kaempferol derivatives. Similarly, Alavarce et al. [10] identified 13 constituents in the hydroalcoholic extract from the aerial parts of E. giganteum by reversed-phase ultra-high-performance liquid chromatography (RP-UHPLC), ultraviolet-visible spectroscopy (UV-Vis), and $M S / M^{n}$ spectra analysis, also detecting styrylpyrones and flavonoid glucosides derivatives of quercetin and kaempferol. Moreover, the alkaloid palustridiene was the only one found in this species in the plant's acid extract in the study conducted by Tipke et al. [56].

The hydroalcoholic extract from aerial parts of E. hyemale L. was characterized by Queiroz et al. [61] by spectrophotometric and HPLC methods with pulsed amperometric detector (PAD) analyses. Phenolic compounds were detected and identified as gallic acid, tannic acid, chlorogenic acid, and caffeic acid. Moreover, Jin et al. [62] identified 9 compounds in the $\mathrm{n}-\mathrm{BuOH}$ fraction obtained from EtOH extract of E. hyemale aerial parts by CC. The authors obtained 8 known compounds, with kaempferol3 -sophoroside-7-O- $\beta$-D-glucopyranoside and kaempferol-7-O- $\alpha$-L-rhamnoside- $4^{\prime}-O-\beta$-D-glycopyranoside being first reported to be isolated from this plant, and a new phenyl glycoside, (2-(sophorosyl)-1-(4-hydroxyphenyl) ethanone).

Regarding E. myriochaetum, the compounds kaempferol-3-O-sophoroside, kaempferol-3,7-diO- $\beta$-glucoside, kaempferol-3-O-sophoroside-4'-O- $\beta$-glucoside, and caffeoyl-methylate-4- $\beta$-glucopyranoside were isolated by Wiedenfeld et al. [63] and Cetto et al. [66] from the watersoluble portion of the aerial parts of this species. Besides, Camacho et al. [64] also isolated the constituents pinocembrin, chrysin, $\beta$-sitosterol, $\beta$-D-glucosylsitosterol, $\beta$-Dglucose, and fatty acids.

As mentioned before, Tipke et al. [56] analyzed the alkaloids present in Equisetum species using HILIC-HPLCESIpos-MS/MS approach. Interestingly, the highest levels of alkaloids were detected in E. palustre samples (close to $1 \mathrm{~g}$ alkaloid per kg), which were mainly dominated by palustrine and palustridiene. Similarly, Cramer et al. [50] screened twenty-two E. palustre samples by the same method. Although the alkaloids' content and distribution suffered variability, palustrine and palustridiene were the main compounds found as well. In addition, another four palustrine-like and three palustridiene-like alkaloids were detected, but only four of them were identified, being $\mathrm{N}^{5}$-formylpalustrine, $\mathrm{N}^{5}$ -
Acetylpalustrine, 18-deoxypalustrine, and $\mathrm{N}^{5}$-formylpalustridiene. Moreover, two related compounds were detected (myricoidine and spermidine). Nevertheless, in the bioassay-guided fractionation study using ethanol (EtOH)induced ulcer model in rats, Gurbuz et al. [35] have obtained, by high-speed centrifugal countercurrent chromatography (HS-CCCC) technique, three fractions from the $\mathrm{n}-\mathrm{BuOH}$ extract of the aerial parts of $E$. palustre, identifying for the first time in this species the compound kaempferol 3-O- $1^{\prime \prime}-\beta-\mathrm{D}$ glucopyranosyl-3-O-1"' $-\beta$-D-glucopyranoside. Posteriorly, Wei et al. [65] have also isolated this compound, together with 4-O-( $p$-coumaroyl)shikimic acid, luteolin-7-O- $\beta$-D-glucopyranoside, quercetin-3-O- $\beta$-D-glucopyranoside, apigenin-5-O$\beta$-D-glucopyranoside, genkwanin-5-O- $\beta$-D-glucopyranoside, luteolin, apigenin, and genkwanin using MSPD extraction and UHPLC-MS/MS. It was also observed that the content of flavonoid was markedly higher than that of flavonoid aglycones. Milovanović et al. [24] studied the hydroalcoholic extract from the sterile stems of this species as well. The predominant constituents were kaempferol glycosides, such as kaempferol 3-O-rutinoside-7-O-sophoroside, kaempferol 3-Orutinoside-7-O-glucoside, and kaempferol 3-O-glucoside, but other compounds were detected in smaller amounts.

Interestingly, in the same abovementioned study, the HPLC profile of E. telmateia hydroalcoholic extract of the sterile stems showed predominance of kaempferol 3,7-Odiglucoside and 5-O-caffeoyl shikimic acid; however, a relatively high content of acetylated flavonoid derivatives such as kaempferol-3-O-(6" -O-acetylglucoside), kaempferol 3-O-(6"-O-acetylglucoside)-7-O-glucoside, and kaempferol 3-O-(6"-O-acetylglucoside)-7-O-rhamnoside has been found, so far exclusively, in this species of the genus. Regarding the aerial parts of E. telmateia, analysis of the aqueous extract and the ethyl acetate fraction by HPLCPAD-ESI/MS performed by Correia et al. [36] allowed the identification of major phenolic compounds such as flavan-3-ol, kaempferol, and phenolic acid derivatives. Retention characteristics and UV spectra also allowed the identification of protocatechuic and $p$ hydroxybenzoic acids and the presence of various caffeic acid derivatives. Further identities assigned to the ethyl acetate fraction compounds from the infusion of E. telmateia are displayed in Table 2.

Finally, in the previously mentioned study carried out by Fons et al. [55] on the volatile profile of fresh aerial parts of Equisetum species, E. palustre showed forty-four volatile organic compounds, mostly lipidic derivatives (1-octen-3-ol, (E)-2-hexenoic acid) and odorous compounds ((E)-2hexenal, $(Z)$-3-hexenol, hexanol, and (E)-2-nonenal), while linalool was the only terpenic derivative identified. E. telmateia was dominated by a large number of isoprenoid derivatives (3-hydroxy-7,8-epoxy- $\beta$-ionol and 3-hydroxy$\alpha$-ionone) as well as one benzenic derivative (3-methoxy-4hydroxystyrene, also called 4-vinylguaiacol). The major volatile constituents in $E$. hyemale derived from the lipidic pathway ((E)-2-heptenal) and shikimic pathway $((E)$ - and (Z)-ferulic acid isomers, 4- vinylguaiacol, and isovanillin), while E. ramosissimum showed the highest amount of shikimic derivatives ((E)-ferulic acid, 4-vinylguaiacol, $(Z)$ - 
ferulic acid, and 2-phenylethanol), but other studies on the chemical composition of the last species mentioned have not been found.

\section{Pharmacological Potential of Equisetum Genus}

4.1. Species with Therapeutic Potential for Kidney Diseases. Carneiro et al. [13] described the diuretic effect of a standardized dried extract of E. arvense (EADE) by monitoring 36 healthy male volunteers' water balance. Through four repeated days, the authors administered EADE (900 mg/day), placebo (corn starch, $900 \mathrm{mg} /$ day), or hydrochlorothiazide $(25 \mathrm{mg} /$ day $)$, separated by a 10 -day washout period. The E. arvense extract was able to significantly induce diuresis similar to the hydrochlorothiazide group, without triggering important variations in the elimination of electrolytes. The clinical checkups and laboratory assessments showed no changes before or after the test, suggesting that the extract of E. arvense is safe for acute use. However, despite the promising results described herein, further research is required to elucidate its diuretic action mechanism.

The ability of the ethanol extract from the roots of E. arvense to impact the urinary bladder activity in rats was studied by Zhang et al. [67], by treating them with a standard diet containing $0.2 \%$ of the extract. After 3 weeks, cystometry with $0.2 \%$ acetic acid solution was done and bladder activity was recorded; in addition, blood pressure, body weight, and adenosine triphosphate (ATP) were measured before and after the stimulation. The control group results showed that during cystometry with acetic acid, the time interval between urinary bladder contractions was shorter, and maximum bladder contraction pressure was much greater. In contrast, the changes observed were lower in the $E$. arvense group. Furthermore, the plasma adrenaline and noradrenaline levels were reduced in the E. arvense group compared to the control group. Besides, the increase in the levels of urinary ATP was smaller in rats treated with E. arvense extract compared to the control group. Therefore, it was demonstrated that the ethanolic extract of root from E. arvense influences urinary bladder activity and can treat urinary bladder disorders.

Gažová et al. [68] performed a clinical study designed to evaluate the efficacy and security of CELcomplex ${ }^{\circledR}$, a preparation comprising a mix of Cucurbita pepo L. seed extract, Equisetum arvense L., and Linum usitatissimum L., on stress urinary incontinence in female patients recruited from 20 urological and gynecological patient clinics in Slovakia. Interestingly, after 12 weeks of treatment $(625 \mathrm{mg}$, two pills for the first 14 days and one pill daily until the end of the treatment), the patients presented a $30 \%$ improvement in urinary incontinence episodes, $40 \%$ improvement in day-time urination frequency, and $64 \%$ gain in nocturnal urinary frequency. However, some side effects were reported, including headache, flatulence, and gastrointestinal discomfort. Indeed, further studies may be needed to determine each plant's isolated effect in this combination and the effectiveness and efficacy of this phytotherapy in other populations.
Recently, the diuretic efficacy of another herbal mixture containing E. arvense was also evaluated clinically. Perna et al. [69] assessed the effectiveness of 4 and 8 weeks of supplementation with highly standardized formula, with Fraxinus ornus L. plus Ananas comosus L., Betula pendula R., Equisetum arvense L., Urtica dioica L., and Pilosella officinarum L. Vaill. dry extract, on the state of hydration and bloating sensation in subjects with high and moderate extracellular water. In this study, 19 women with extracellular water over $45 \%$ completed the study and their data were analyzed at baseline, at 30 and 60 days. Bioimpedance, short form with 36 questions, and anthropometric parameters were assessed. The extracellular water decreased at 30 and 60 days, as well as the fat mass. Improvement of free fat mass was measured but not on the bloating sensation survey at 60 days. Again, similarly to Gažová et al. [68], further studies may be needed to determine each plant's isolated effect and the efficacy of this herbal mix in other populations.

Another study evaluating the botanical formulation containing Herniaria glabra L., Agropyron repens, Equisetum arvense L., and Sambucus nigra L. was undertaken to explore the preventive role of this combination in an experimental model of nephrolithiasis induced by the oral treatment with $0.75 \%$ ethylene glycol (EG) and $1 \%$ ammonium chloride for three days, followed by 15 days with only EG. The groups received different doses of the formulation, ranging from $30 \mathrm{mg} / \mathrm{kg}$ to $500 \mathrm{mg} / \mathrm{kg}$. The results revealed that the group treated with $125 \mathrm{mg} / \mathrm{kg}$ of the formulation had a significant lower calcium oxalate crystals deposits amount when compared with the placebo-only treated group. All the doses significantly diminished the quantity of microcalcifications and reduced the number of kidneys affected by subcapsular fibrosis. Besides, the doses of $125 \mathrm{mg} / \mathrm{kg}$ and $500 \mathrm{mg} / \mathrm{kg}$ were able to induce diuresis. Although the study has not explored the effects of the species in isolation, this formulation's potential is evident and significant [70]. Indeed, more studies are needed to investigate the mechanisms responsible for the effect and the safe use of these preparations.

Although the main purpose of this review is to discuss the scientific findings of the different Equisetum species, it is important to mention that some compounds isolated from these species have already revealed beneficial actions regarding their ability to induce diuresis. In this context, the flavonoid luteolin, found in the aerial parts of E. arvense and E. palustre, induced both diuretic and natriuretic effect in normotensive and hypertensive rats, without interfering with urinary $\mathrm{pH}, \mathrm{K}^{+}$, or $\mathrm{Cl}^{-}$levels. This study also showed the involvement of muscarinic acetylcholine receptors for luteolin renal effects [71]. Besides, the diuretic activity of isoquercitrin (quercetin 3-O-glucoside), a compound also found in E. arvense aerial parts, was studied by Gasparotto et al. [72]. The flavonoid showed diuretic activity in a 7-day repeated-dose study in spontaneously hypertensive rats (SHR). Isoquercitrin $\left(10 \mathrm{mg} / \mathrm{kg}\right.$, p.o.) increased $\mathrm{Na}^{+}$excretion and presented $\mathrm{K}^{+}$-sparing effects similar to spironolactone. Those effects were related to angiotensin-converting enzyme inhibition; increased bioavailability of bradykinin, PGI2, nitric oxide; and inhibitory effect on renal $\mathrm{Na}^{+} / \mathrm{K}^{+}$-ATPase activity. 
Moreover, the treatment with oleanolic acid ( $3 \beta$-hydroxyolea-12-en-28-oic acid) at $60 \mathrm{mg} / \mathrm{kg} /$ day for 4 weeks has demonstrated antihypertensive effect in L-NAME-induced hypertension in rats by promoting diuresis and increasing $\mathrm{Na}^{+}$excretion compared to the L-NAME group, in addition to inducing nephroprotection [73].

Extracts from E. giganteum and E. bogotense have demonstrated a diuretic activity in laboratory animals $[18,48]$. Further, the diuretic activity of E. bogotense was also evaluated in healthy volunteers through their water balance by Lemus et al. [18]. In addition to biochemical parameters, such as urinary electrolyte concentration, urine density, osmolarity, and $\mathrm{pH}$ value, clinical observations on arterial pressure and any adverse reactions were also determined. A $10 \%$ E. bogotense infusion showed a significant diuretic effect in healthy subjects compared to the control group. Besides, none of the volunteers reported any evidence of adverse reaction, nor did they show any change in blood pressure. Urinary electrolytes showed a significant increase in $\mathrm{Na}^{+}, \mathrm{K}^{+}$, and $\mathrm{Cl}^{-}$excretion compared to the control group, but inside the usual physiological values. Despite the great variation in diuresis excretion levels of the subjects, the study results suggest that an infusion of $E$. bogotense could be used to induce diuresis. As mentioned before, little information is available regarding the chemical composition of this species; only the alkaloids nicotine, palustrine, and palustridiene were identified. Of those, nicotine was described as antidiuretic [74], while the other alkaloids' effect remains unknown.

Gutiérrez et al. [75] proved that the chloroform extracts of some species of Equisetum genus, including the E. fluviatile, E. hyemale var. affine, E. giganteum, and E. myriochaetum, at dose of $50 \mathrm{mg} / \mathrm{kg}$, presented acute diuretic activity in CD1 strain mice using hydrochlorothiazide, spironolactone, and furosemide as standard drugs for comparison (given at a dose of $25 \mathrm{mg} / \mathrm{kg}$ ). It was found that the most active plant was E. hyemale var. affine, followed by E. fluviatile, E. giganteum, and E. myriochaetum, producing an effect similar to hydrochlorothiazide in relation to the excretion of $\mathrm{Na}^{+}, \mathrm{K}^{+}$, and $\mathrm{Cl}^{-}$. Besides, gallic acid, found in the aerial parts of E. hyemale, also exhibited a diuretic effect when orally given to normotensive and hypertensive rats, an effect associated with increased $\mathrm{Na}^{+}$ and $\mathrm{Cl}^{-}$levels in the urine. This study also showed the endogenous prostanoid generation's involvement in the renal effects induced by gallic acid [76]. Moreover, caffeic acid, found in the species E. giganteum, E. hyemale, and E. telmateia, induced diuresis in normotensive rats, associated with an increased urinary $\mathrm{Na}^{+}$and $\mathrm{K}^{+}$elimination and a urinary $\mathrm{Ca}^{2+}$-sparing effect. In agreement with these findings, this study also demonstrated, by using an in vitro assay of urinary calculus formation, that the caffeic acid reduced the number of the monohydrate and dihydrate forms of calcium oxalate crystals formed in the urine, suggesting the diuretic plus antiurolithiatic effect of this compound [77]. On the other hand, it is important to mention that kaempferol, a compound found in many species of the Equisetum genus, was studied by CechinelZanchet et al. [78], but did not present diuretic action.
A last compound of interest found in the species E. giganteum, E. ramosissimum, and E. debile is ferulic acid, which has been reported as nephroprotective in a great number of studies conducted on animals. This phenolic acid has been shown to reduce liver and renal oxidative damage induced by cadmium [79], as well as hyperglycemia- [80], lipopolysaccharide- [81], or methotrexate- [82] induced kidney nephrotoxicity by attenuating inflammation process and reducing oxidative stress. For instance, Alam et al. [83] have shown that chronic treatment with ferulic acid $(50 \mathrm{mg} / \mathrm{kg})$ also reduced systolic blood pressure of SHR animals and Wistar rats receiving L-NAME for 8 weeks. This compound was able to reduce left ventricular diastolic stiffness and attenuate inflammatory cell infiltration, ferric iron accumulation, and collagen deposition in left ventricles and kidneys in both models of hypertension. Moreover, ferulic acid improved both endothelium-dependent relaxation in isolated thoracic aortic rings and antioxidative balance in the heart and kidneys. Finally, we can suggest that these compounds, at least in part, seem to contribute to the pharmacological effects described by these species. However, many compounds have not yet been the subject of studies that specifically target these biological activities, so there is a fruitful field to be explored in the future.

\section{Other Properties of Pharmacological Interest}

Do Monte et al. [84] described the antinociceptive and antiinflammatory effects of hydroalcoholic extract of stems from E. arvense in mice. Briefly, the results of the present study demonstrated that the extract exhibits an antinociceptive effect in chemical models of nociception. In agreement with these results, Steinbor et al. [85] verified the anti-inflammatory properties of $E$. arvense through its silica content, revealing that silica-rich horsetail preparations suppress lymphocytes' activation and proliferation by an interleukin-2-dependent mechanism and a downregulation of interferon gamma (IFN- $\gamma$ ). Interestingly, analytical profiling by HPLC-UV-MS and bioactivity testing revealed significative immunosuppressive concentrations of a component that was identified as isoquercitrin. Thus, the authors concluded that both silica and isoquercitrin are active compounds of horsetail preparations. The anti-inflammatory and antinociceptive effects of $E$. arvense have also been investigated in clinical studies. In one of them, five herbs (including E. arvense) plus thiamine reduced the pain and improved functional mobility in patients with pain [86]. The complex of 5 herbs, plus vitamin B1, was well tolerated. The results suggest that the blend should be considered a valuable alternative treatment in managing chronic musculoskeletal pain. However, the exact contribution of $E$. arvense in these clinical results still needs to be quantified.

E. arvense has also been described as a promising source of anticancer compounds and its ethanol extract showed a cytotoxic effect on HeLa (cervical cancer cells), HT-29 (colorectal adenocarcinoma), and MCF7 (breast cancer) cell line [87]. Moreover, Alexandru et al. [88] reported that the 
TABLE 3: Pharmacological properties of Equisetum genus stratified by effect, key findings, and species.

\begin{tabular}{|c|c|c|c|}
\hline Effect & Key findings & Species & Reference \\
\hline \multirow{3}{*}{ Diuretic activity } & $\begin{array}{l}\text { Increased excretion of sodium, potassium, and } \\
\text { chloride }\end{array}$ & $\begin{array}{c}\text { Equisetum fluviatile } \\
\text { Equisetum hyemale var. affine } \\
\text { Equisetum giganteum } \\
\text { Equisetum myriochaetum }\end{array}$ & {$[75]$} \\
\hline & $\begin{array}{l}\text { Increased excretion of sodium, potassium, and } \\
\text { chloride* }\end{array}$ & Equisetum bogotense & {$[18]$} \\
\hline & $\begin{array}{c}\text { No effects on the urinary excretion of } \\
\text { electrolytes* }\end{array}$ & Equisetum arvense $L$. & {$[13]$} \\
\hline $\begin{array}{l}\text { Urinary bladder } \\
\text { disorders }\end{array}$ & $\begin{array}{c}\text { Increased interval between urinary bladder } \\
\text { contractions and decreased bladder contraction } \\
\text { pressure }\end{array}$ & Equisetum arvense $L$. & {$[67]$} \\
\hline Urinary incontinence & $\begin{array}{l}\text { Improvement in urinary incontinence } \\
\text { episodes; day-time urination frequency; and } \\
\text { gain in nocturnal urinary frequency* }\end{array}$ & $\begin{array}{l}\text { CELcomplex }{ }^{\circledR} \text { (Cucurbita pepo L.; Equisetum } \\
\text { arvense L.; and Linum usitatissimum L.) }\end{array}$ & {$[68]$} \\
\hline $\begin{array}{l}\text { State of hydration and } \\
\text { bloating sensation }\end{array}$ & Decreased extracellular water and fat mass* & $\begin{array}{l}\text { Formula (Fraxinus ornus L.; Ananas comosus L.; } \\
\text { Betula pendula R.; Equisetum arvense L.; Urtica } \\
\text { dioica L; and Pilosella officinarum L. Vaill.) }\end{array}$ & {$[69]$} \\
\hline Nephrolithiasis & Lower calcium oxalate crystals & $\begin{array}{l}\text { Formula (Herniaria glabra L.; Agropyron repens; } \\
\text { Equisetum arvense L.; and Sambucus nigra L.) }\end{array}$ & {$[70]$} \\
\hline \multirow{2}{*}{ Antinociceptive effect } & $\begin{array}{l}\text { Inhibitory action on chemically induced acute } \\
\text { pain test }\end{array}$ & Equisetum arvense L. & {$[84]$} \\
\hline & $\begin{array}{l}\text { Reduction of clinical chronic musculoskeletal } \\
\text { pain* }\end{array}$ & Equisetum arvense $L$. & {$[86]$} \\
\hline \multirow{3}{*}{$\begin{array}{l}\text { Anti-inflammatory } \\
\text { effect } \\
\text { Cytotoxic and } \\
\text { anticancer effect }\end{array}$} & Anti-inflammatory action on COPD model & Equisetum arvense $L$. & {$[85]$} \\
\hline & Reduction of antigen-induced arthritis model & Equisetum giganteum $L$. & [9] \\
\hline & Reduction in cell viability of cancer cells & Equisetum arvense $L$. & {$[87-90]$} \\
\hline \multirow{4}{*}{ Effect on bone diseases } & Increase in calcium absorption & Equisetum arvense $L$. & {$[92]$} \\
\hline & $\begin{array}{l}\text { Proliferation of osteoblasts or inhibitory action } \\
\text { in osteoclasts }\end{array}$ & Equisetum arvense $L$. & {$[38,94]$} \\
\hline & Bone resorption markers of rats & Equisetum arvense $L$. & {$[95]$} \\
\hline & Bone mineral density of rats & Equisetum arvense $L$. & {$[95,96]$} \\
\hline \multirow{3}{*}{ Antidiabetic } & $\begin{array}{l}\text { Beneficial effects in streptozotocin-induced } \\
\text { diabetic rats }\end{array}$ & Equisetum myriochaetum Schlecht. and Cham. & {$[66]$} \\
\hline & $\begin{array}{l}\text { Clinically beneficial to recently diagnosed type } \\
2 \text { diabetic patients* }\end{array}$ & Equisetum myriochaetum Schlecht. and Cham. & [99] \\
\hline & $\begin{array}{l}\text { Beneficial effects in alloxan-induced diabetic } \\
\text { rabbits }\end{array}$ & Equisetum giganteum L. & {$[97]$} \\
\hline \multirow{6}{*}{$\begin{array}{l}\text { Antioxidant and } \\
\text { antimicrobial }\end{array}$} & $\begin{array}{c}\text { Reduction in oxidative stress } \\
\text { Antimicrobial activity }\end{array}$ & $\begin{array}{l}\text { Equisetum arvense } L . \\
\text { Equisetum giganteum } L .\end{array}$ & $\begin{array}{c}{[101]} \\
{[10,28,98]}\end{array}$ \\
\hline & $\begin{array}{c}\text { Antioxidant and antimicrobial of supercritical } \\
\text { fluid extraction }\end{array}$ & Equisetum telmateia Ehrh. & {$[40]$} \\
\hline & $\begin{array}{l}\text { Bactericidal, fungicidal, and antiprotozoal } \\
\text { effect }\end{array}$ & Equisetum hyemale L. & {$[61,100]$} \\
\hline & Bactericidal and fungicidal activity & $\begin{array}{l}\text { Equisetum arvense } L . \\
\text { Equisetum arvense } L .\end{array}$ & {$[91]$} \\
\hline & $\begin{array}{l}\text { Radical scavenger activity and antimicrobial } \\
\text { activity }\end{array}$ & $\begin{array}{c}\text { Equisetum ramosissimum Desf. and Equisetum } \\
\text { telmateia } \text { Ehrh. } \\
\text { Equisetum arvense } L . \\
\text { Equisetum sylvaticum } L . \\
\text { Equisetum fluviatile } L . \\
\text { Equisetum palustre } L . \\
\text { Equisetum telmateia } \text { Ehrh. }\end{array}$ & {$[102]$} \\
\hline & $\begin{array}{l}\text { Radical scavenger activity and antimicrobial } \\
\text { activity }\end{array}$ & Equisetum telmateia Ehrh. & {$[47]$} \\
\hline \multirow[b]{2}{*}{$\begin{array}{l}\text { Effects on central } \\
\text { nervous system }\end{array}$} & Anticonvulsant and sedative effects & Equisetum arvense $L$. & {$[103]$} \\
\hline & $\begin{array}{l}\text { Prolonged the ketamine-induced total sleeping } \\
\text { time and decreased the locomotor activity in } \\
\text { mice }\end{array}$ & Equisetum arvense $L$. & {$[104]$} \\
\hline Antiulcer & $\begin{array}{c}\text { Gastroprotective potential against different } \\
\text { ulcerogenic agents }\end{array}$ & Equisetum palustre $L$. & {$[35]$} \\
\hline
\end{tabular}

${ }^{*}$ Clinical study. 
aqueous extract from sterile stems of $E$. arvense exerted concentration dependent cytotoxic effects on human leukemic cells (U937 cells). The results from Al Mohammed et al. [89] demonstrated that the ethanolic extract of $E$. arvense presented cytotoxicity and decreased the cell viability of adenocarcinomic human alveolar basal epithelial cells (A549 cells). Recently, Bhat et al. [90] studied the cytotoxic and suppressive action of the ethanolic extract of $E$. arvense against human pancreatic carcinoma cell line ASPC-1. The extract showed potential cytotoxicity and reduced the cellular proliferation of these cells. Similarly, a very strong antimicrobial action of volatile constituents of the E. arvense was reported by Radulović et al. [91] against the bacteria Staphylococcus aureus, Escherichia coli, Klebsiella pneumoniae, Pseudomonas aeruginosa, and Salmonella enteritidis and the fungi Aspergillus niger and Candida albicans. Remarkably, the essential oil of E. arvense is shown to possess a broad spectrum of a robust antimicrobial activity against all tested strains.

E. arvense for the treatment of osteoporosis has been extensively studied, mainly because it contains a substantial quantity of silica and its ingesting leads to the absorption and use of calcium and the formation of collagen [92]. Besides, it contains several secondary metabolites that help prevent bone loss caused by age and estrogen deficiency [93]. Furthermore, the osteoblasts' proliferative effects of E. arvense together with its inhibitory action in osteoclasts functions have also been described [38, 94]. Corroborating these results, Kotwal and Badole [95] confirmed the beneficial effects of an extract of E. arvense on the bone mineral density of rats submitted to ovariectomy. Finally, Arbabzadegan et al. [96] also confirmed these E. arvense extract effects by analyzing the mandibular bone mineral density from rats.

E. giganteum has been traditionally used as an antidiabetic herbal remedy to treat diabetes. Recently, Vieira et al. [97] investigated the antidiabetic effects of the butanolic and aqueous extracts from E. giganteum in an animal model of diabetes. Both aqueous and butanolic extracts could significantly reduce glucose, cholesterol, and triacylglycerol, thus demonstrating their hypolipidemic and hypoglycemic effects. E. giganteum has also been intensively studied with the aim of preventing oral diseases because some studies showed its antimicrobial activity $[10,28,98]$. Also, despite the use of E. giganteum as a diuretic medicinal plant, Farinon et al. [9] evaluated the effect of its aqueous extract as immunomodulatory therapy in a model of antigen-induced arthritis (AIA). The treatment with the extract reduced nociception at 3,6 , and $24 \mathrm{~h}$, decreased leukocyte migration, and inhibited lymphocyte proliferation. In conclusion, it was confirmed that E. giganteum extract has an anti-inflammatory and immunomodulatory potential in the acute inflammation model.

Studies in streptozotocin-induced diabetic rats showed that water and butanol extracts of the aerial parts of E. myriochaetum have significant hypoglycemic activity in an animal model [66]. Revilla et al. [99] also described the hypoglycemic effect of E. myriochaetum through a clinical trial. Type 2 diagnosed diabetic patients were analyzed and received a quantity of $0.33 \mathrm{~g} / \mathrm{kg}$ of dried plant (aerial parts).
This single dose of the extract significantly reduced the patients' blood glucose levels, proving a promising potential of this species in the therapeutic management of diabetic individuals.

Yeganegi et al. [40] evaluated E. telmateia extracts' antimicrobial activity against Staphylococcus aureus, Bacillus cereus, Escherichia coli, Salmonella typhi, and Candida albicans. The results of this group of authors showed that the extract of E. telmateia exhibited the highest antimicrobial potency against $S$. aureus. Besides, regarding the antimicrobial potential of another species, E. hyemale, two articles were found. The first was contributed by Queiroz et al. [61], who showed an antifungal activity of the extract against dermatophyte fungi (Trichophyton rubrum and Microsporum canis). The second, published by Alves et al. [100], showed the antibiofilm, antimicrobial, and antiparasitic potential of E. hyemale extract against several infectious agents (bacteria, fungi, Mycobacterium, and Trypanosomes).

All the pharmacological activities described here can benefit in parallel the therapeutic management of kidney disorders. The anti-inflammatory activity related to some species could mitigate the damage caused by the high blood pressure levels suffered by the kidneys during systemic arterial hypertension or even the damage caused by diabetes. Accordingly, some species have also demonstrated significant antidiabetic actions. In addition, regarding the antimicrobial actions described by some species, these could have a significantly useful application against genitourinary infections, which could also benefit kidney damage. The multiple therapeutic possibilities for plants of the Equisetum genus are evident; however, many studies are needed to evaluate both the pharmacological potential and the safety concerning the use of the preparations. Finally, Table 3 summarizes the main scientific findings that demonstrate the therapeutic effects of different species of Equisetum in kidney disorders and other biological activities.

\section{Final Considerations}

This review reveals that the most widespread traditional use of Equisetum is as diuretic, followed by the treatment of genitourinary diseases. The most popular species from the Equisetum genus with medicinal use is E. arvense. Other species also demonstrate beneficial effects in experimental assays for different pharmacological purposes. However, few in vivo toxicity studies were conducted so far for most species, so there is no consensus on effective and toxic dosage. Hence, many species need to be explored in detail for scientific validation of popular use to induce diuresis and treat kidney and other associated diseases.

\section{Conflicts of Interest}

The authors declare that they have no conflicts of interest.

\section{Acknowledgments}

The authors are grateful for the support received from the Coordenação de Aperfeiçoamento de Pessoal de Nível 
Superior (CAPES), Conselho Nacional de Desenvolvimento Científico e Tecnológico $(\mathrm{CNPq})$, Fundação de Apoio à Pesquisa Científica e Tecnológica do Estado de Santa Catarina (FAPESC), and Universidade do Vale do Itajaí (UNIVALI). Moreover, TB is grateful for the postdoctoral scholarship and financial support from PDJ/CNPq.

\section{Supplementary Materials}

Figure S1: chemical structure of the compounds identified in the Equisetum genus. Chemical structures are presented followed by their names, molecular weights, and references. (Supplementary Materials)

\section{References}

[1] M. I. Calvo and R. Y. Cavero, "Medicinal plants used for cardiovascular diseases in Navarra and their validation from Official sources," Journal of Ethnopharmacology, vol. 157, pp. 268-273, 2014.

[2] C. I. Wright, L. Van-Buren, C. I. Kroner, and M. M. G. Koning, "Herbal medicines as diuretics: a review of the scientific evidence," Journal of Ethnopharmacology, vol. 114, no. 1, pp. 1-31, 2007.

[3] S. Olsen, Encyclopedia of Garden Ferns, Timber Press, Portland, OR, USA, 1st edition, 2007.

[4] D. Bown, The Herb Society of America, Encyclopedia of Herbs \& Their Uses, Dorling Kindersley Publishing Inc, New York, NY, USA, 1995.

[5] R. Boorhem, Reader's Digest- Segredos e Virtudes das Plantas Medicinais, Reader's Digest Brasil Ltda., Rio de Janeiro, Brazil, 1999.

[6] W. B. Mors, C. Rizzini, and P. Pereira, Medicinal Plants of Brazil, Algonac: Reference Publications, Inc, Algonac, MI, USA, 2000.

[7] P. D. A. E. Al-Snafi, "The pharmacology of Equisetum arvense-A review," IOSR Journal of Pharmacy (IOSRPHR), vol. 07, no. 02, pp. 31-42, 2017.

[8] R. Quiroga, L. Meneses, and R. W. Bussmann, "Medicinal ethnobotany in huacareta (chuquisaca, Bolivia)," Journal of Ethnobiology and Ethnomedicine, vol. 8, 2012.

[9] M. Farinon, P. S. Lora, L. N. Francescato et al., "Effect of aqueous extract of giant horsetail (equisetum giganteum L.) in antigen-induced arthritis," The Open Rheumatology Journal, vol. 7, no. 1, pp. 129-133, 2014.

[10] R. A. S. Alavarce, L. L. Saldanha, N. L. M. Almeida et al., "The beneficial effect of equisetum giganteum L. against Candida biofilm formation: new approaches to denture stomatitis," Evidence-Based Complementary and Alternative Medicine, vol. 2015, 2015.

[11] M. L. Dickel, S. M. K. Rates, and M. R. Ritter, "Plants popularly used for loosing weight purposes in Porto Alegre, South Brazil," Journal of Ethnopharmacology, vol. 109, no. 1, pp. 60-71, 2007.

[12] D. Garcia, M. V. Domingues, and E. Rodrigues, "Ethnopharmacological survey among migrants living in the southeast atlantic forest of Diadema, São Paulo, Brazil," Journal of Ethnobiology and Ethnomedicine, vol. 6, 2010.

[13] D. M. Carneiro, R. C. Freire, T. C. D. D. Honório et al., "Randomized, double-blind clinical trial to assess the acute diuretic effect of equisetum arvense (field horsetail) in healthy volunteers," Evidence-Based Complementary and Alternative Medicine, vol. 2014, 2014.
[14] A. N. Castañeda Sortibrán, M. G. Ordaz Téllez, A. AndradeCetto, C. S. Kischinevzky, and R. Rodríguez-Arnaiz, "Antimutagenic activity of two medicinal phytoextracts in somatic cells ofDrosophila melanogaster," Pharmaceutical Biology, vol. 49, no. 6, pp. 640-647, 2011.

[15] G. Mata-Torres, A. Andrade-Cetto, F. A. EspinozaHernández et al., "Hepatic glucose output inhibition by Mexican plants used in the treatment of type 2 diabetes," Frontiers in Pharmacology, vol. 11, 2020.

[16] A. Andrade-Cetto, J. Becerra-Jiménez, and R. CárdenasVázquez, "Alfa-glucosidase-inhibiting activity of some Mexican plants used in the treatment of type 2 diabetes," Journal of Ethnopharmacology, vol. 116, no. 1, pp. 27-32, 2008.

[17] A. Andrade-Cetto and M. Heinrich, "Mexican plants with hypoglycaemic effect used in the treatment of diabetes," Journal of Ethnopharmacology, vol. 99, no. 3, pp. 325-348, 2005.

[18] I. Lemus, R. García, S. Erazo, R. Peña, M. Parada, and M. Fuenzalida, "Diuretic activity of an Equisetum bogotense tea (Platero herb): evaluation in healthy volunteers," Journal of Ethnopharmacology, vol. 54, no. 1, pp. 55-58, 1996.

[19] E. B. Marc, A. Nelly, D.-D. Annick, and D. Frederic, "Plants used as remedies antirheumatic and antineuralgic in the traditional medicine of Lebanon," Journal of Ethnopharmacology, vol. 120, no. 3, pp. 315-334, 2008.

[20] D. Dragos, M. Gilca, L. Gaman et al., "Phytomedicine in joint disorders," Nutrients, vol. 9, no. 1, pp. 1-18, 2017.

[21] M. Gilca, G. S. Tiplica, and C. M. Salavastru, "Traditional and ethnobotanical dermatology practices in Romania and other Eastern European countries," Clinics in Dermatology, vol. 36, no. 3, pp. 338-352, 2018.

[22] C. Gründemann, K. Lengen, B. Sauer et al., "Equisetum arvense (common horsetail) modulates the function of inflammatory immunocompetent cells," BMC Complementary and Alternative Medicine, vol. 14, no. 1, 2014.

[23] K. Šavikin, G. Zdunić, N. Menković et al., "Ethnobotanical study on traditional use of medicinal plants in SouthWestern Serbia, Zlatibor District," Journal of Ethnopharmacology, vol. 146, no. 3, pp. 803-810, 2013.

[24] V. Milovanović, N. Radulović, Z. Todorović et al., "Antioxidant, antimicrobial and genotoxicity screening of hydroalcoholic extracts of five Serbian Equisetum species," Plant Foods for Human Nutrition, vol. 62, no. 3, pp. 113-119, 2007.

[25] H. Oh, D.-H. Kim, J.-H. Cho, and Y.-C. Kim, "Hepatoprotective and free radical scavenging activities of phenolic petrosins and flavonoids isolated from Equisetum arvense," Journal of Ethnopharmacology, vol. 95, no. 2-3, pp. 421-424, 2004.

[26] P. H. Li, Y. P. Chiu, C. C. Shih et al., "Biofunctional activities of equisetum ramosissimum extract: protective effects against oxidation, melanoma, and melanogenesis," Oxidative Medicine and Cellular Longevity, vol. 2016, 2016.

[27] H. Li, P. Wang, Q. Liu, X. Cheng, Y. Zhou, and Y. Xiao, "Cell cycle arrest and cell apoptosis induced by Equisetum hyemale extract in murine leukemia L1210 cells," Journal of Ethnopharmacology, vol. 144, no. 2, pp. 322-327, 2012.

[28] P. Kloucek, Z. Polesny, B. Svobodova, E. Vlkova, and L. Kokoska, "Antibacterial screening of some Peruvian medicinal plants used in Callería District," Journal of Ethnopharmacology, vol. 99, no. 2, pp. 309-312, 2005.

[29] S. E. Giraldo Quintero, M. C. Bernal Lizarazú, A. Morales Robayo, A. Z. Pardo Lobo, and L. Gamba Molano, "Descripción del uso tradicional de plantas medicinales en 
mercados populares de Bogotá, D.C,” Nova, vol. 13, no. 23, pp. 73-80, 2015.

[30] P. Ishtiyak and S. A. Hussain, "Traditional use of medicinal plants among tribal communities of bangus valley, kashmir himalaya, India," Studies on Ethno-Medicine, vol. 11, no. 4, pp. 318-331, 2017.

[31] S. Vitalini, M. Iriti, C. Puricelli, D. Ciuchi, A. Segale, and G. Fico, "Traditional knowledge on medicinal and food plants used in Val San Giacomo (Sondrio, Italy)-An alpine ethnobotanical study," Journal of Ethnopharmacology, vol. 145, no. 2, pp. 517-529, 2013.

[32] M. Zovko Končić and K. Bljajić, "Chapter 42-traditional herbal products used for the management of diabetes in Croatia: linking traditional use with $\alpha$-glucosidase-inhibitory activity," in Bioactive Food as Dietary Interventions for Diabetes, R. R. Watson and V. R. Preedy, Eds., pp. 647-664, Academic Press, Cambridge, MA, USA, Second edition, 2019.

[33] E. E. Tsioutsiou, P. Giordani, E. Hanlidou et al., "Ethnobotanical study of medicinal plants used in Central Macedonia, Greece," Evidence-Based Complementary and Alternative Medicine, vol. 2019, 2019.

[34] E. Uzun, G. Sariyar, A. Adsersen et al., "Traditional medicine in Sakarya province (Turkey) and antimicrobial activities of selected species," Journal of Ethnopharmacology, vol. 95, no. 2-3, pp. 287-296, 2004.

[35] I. Gurbuz, E. Yesilada, and S. Ito, "An anti-ulcerogenic flavonol diglucoside from Equisetum palustre L," Journal of Ethnopharmacology, vol. 121, no. 3, pp. 360-365, 2009.

[36] H. Correia, A. González-Paramás, M. T. Amaral, C. SantosBuelga, and M. T. Batista, "Characterisation of polyphenols by HPLC-PAD-ESI/MS and antioxidant activity inEquisetum telmateia," Phytochemical Analysis, vol. 16, no. 5, pp. 380-387, 2005.

[37] R. Nunes, P. Pasko, M. Tyszka-Czochara, A. Szewczyk, M. Szlosarczyk, and I. S. Carvalho, "Antibacterial, antioxidant and anti-proliferative properties and zinc content of five south Portugal herbs," Pharmaceutical Biology, vol. 55, no. 1, pp. 114-123, 2017.

[38] J. Costa-Rodrigues, S. C. Carmo, J. C. Silva, and M. H. R. Fernandes, "Inhibition of humanin vitroosteoclastogenesis byEquisetum arvense," Cell Proliferation, vol. 45 , no. 6, pp. 566-576, 2012.

[39] A. Asgharikhatooni, S. Bani, S. Hasanpoor et al., "The effect of equisetum arvense (horse tail) ointment on wound healing and pain intensity after episiotomy: a randomized placebocontrolled trial," Iranian Red Crescent Medical Journal, vol. 17, no. 3, pp. 1-7, 2015.

[40] M. Yeganegi, F. Tabatabaei Yazdi, S. A. Mortazavi, J. Asili, B. Alizadeh Behbahani, and A. Beigbabaei, "Equisetum telmateia extracts: chemical compositions, antioxidant activity and antimicrobial effect on the growth of some pathogenic strain causing poisoning and infection," Microbial Pathogenesis, vol. 116, pp. 62-67, 2018.

[41] W. Chaiyana, C. Punyoyai, S. Somwongin et al., "Inhibition of $5 \alpha$-reductase, IL- 6 secretion, and oxidation process of equisetum debile roxb. Ex vaucher extract as functional food and nutraceuticals ingredients," Nutrients, vol. 9, no. 10, 2017.

[42] R. Y. Cavero and M. I. Calvo, "Medicinal plants used for musculoskeletal disorders in Navarra and their pharmacological validation," Journal of Ethnopharmacology, vol. 168, pp. 255-259, 2015.
[43] N. C. D. V. Baracho, B. B. V. Vicente, G. D. A. S. Arruda, B. C. F. Sanches, and J. D. Brito, "Study of acute hepatotoxicity of Equisetum arvense L. in rats," Acta Cirurgica Brasileira, vol. 24, no. 6, pp. 449-453, 2009.

[44] Y. Tago, M. Wei, N. Ishii, A. Kakehashi, and H. Wanibuchi, "Evaluation of the subchronic toxicity of dietary administered equisetum arvense in F344 rats," Journal of Toxicologic Pathology, vol. 23, no. 4, pp. 245-251, 2010.

[45] J. A. Ortega García, M. G. Angulo, E. J. Sobrino-Najul et al., "Prenatal exposure of a girl with autism spectrum disorder to 'horsetail' (Equisetum arvense) herbal remedy and alcohol: a case report," Journal of Medical Case Reports, vol. 5, 2011.

[46] B. Fabre, B. Geay, and P. Beaufils, "Thiaminase activity in equisetum arvense and its extracts," Plantes médicinales et phytothérapie, vol. 26, no. 3, pp. 190-197, 1993.

[47] I. D. Radojevic, M. S. Stankovic, O. D. Stefanovic et al., "Great horsetail (equisetum telmateia Ehrh.): active substances content and biological effects," EXCLI Journal, vol. 11, pp. 59-67, 2012.

[48] G. Schmeda-Hirschmann, J. I. Loyola, J. Sierra, R. Retamal, and J. Rodriguez, "Hypotensive effect and enzyme inhibition activity of mapuche medicinal plant extracts," Phytotherapy Research, vol. 6, no. 4, pp. 184-188, 1992.

[49] M. G. O. Téllez, H. B. Rodríguez, G. Q. Olivares, A. N. C. Sortibrán, A. A. Cetto, and R. Rodríguez-Arnaiz, "A phytotherapeutic extract of Equisetum myriochaetum is not genotoxic either in the in vivo wing somatic test of Drosophila or in the in vitro human micronucleus test," Journal of Ethnopharmacology, vol. 111, no. 1, pp. 182-189, 2007.

[50] L. Cramer, L. Ernst, M. Lubienski et al., "Structural and quantitative analysis of Equisetum alkaloids," Phytochemistry, vol. 116, no. 1, pp. 269-282, 2015.

[51] M. Veit, H. Geiger, B. Kast et al., "Styrylpyrone glucosides from equisetum," Phytochemistry, vol. 39, no. 4, pp. 915-917, 1995.

[52] N. Mimica-Dukic, N. Simin, J. Cvejic, E. Jovin, D. Orcic, and B. Bozin, "Phenolic compounds in field horsetail (equisetum arvense L.) as natural antioxidants," Molecules, vol. 13, no. 7, pp. 1455-1464, 2008.

[53] Y. Ganeva, C. Chanev, and T. Dentchev, "Triterpenoids and sterols from equiseturn arvense," Dokladi na Bulgarskata Akademiya na Naukite, vol. 54, no. 2, pp. 53-56, 2001.

[54] J. Chang, L.-J. Xuan, and Y.-M. Xu, "Three new phenolic glycosides from the fertile sprouts of equisetum arvense," Journal of Integrative Plant Biology, vol. 43, no. 2, pp. 193197, 2001.

[55] F. Fons, D. Froissard, J.-M. Bessière et al., "Volatile composition of six horsetails: prospects and perspectives," Natural Product Communications, vol. 8, no. 4, pp. 509-512, 2013.

[56] I. Tipke, L. Bücker, J. Middelstaedt, P. Winterhalter, M. Lubienski, and T. Beuerle, "HILIC HPLC-ESI-MS/MS identification and quantification of the alkaloids from the genus Equisetum," Phytochemical Analysis, vol. 30, no. 6, pp. 669-678, 2019.

[57] J.-M. Tan, Y.-H. Qiu, X.-Q. Tan, C.-H. Tan, and K. Xiao, "Chemical constituents ofEquisetum debile," Journal of Asian Natural Products Research, vol. 13, no. 9, pp. 811-816, 2011.

[58] X.-H. Xu, C.-H. Tan, S.-H. Jiang, et al.,D.-Y. Zhu, "Debilosides A-C: three new megastigmane glucosides fromEquisetum debile," Helvetica Chimica Acta, vol. 89, no. 7, pp. 1422-1426, 2006. 
[59] T. Kanchanapoom, H. Otsuka, and S. Ruchirawat, "Megastigmane glucosides from Equisetum debile and E. diffusum," Chemical \& Pharmaceutical Bulletin, vol. 55, no. 8, pp. 1277-1280, 2007.

[60] L. N. Francescato, S. L. Debenedetti, T. G. Schwanz, V. L. Bassani, and A. T. Henriques, "Identification of phenolic compounds in Equisetum giganteum by LC-ESI-MS/ MS and a new approach to total flavonoid quantification," Talanta, vol. 105, pp. 192-203, 2013.

[61] G. M. De Queiroz, F. A. S. Politi, E. R. Rodrigues et al., "Phytochemical characterization, antimicrobial activity, and antioxidant potential of equisetum hyemale L. (Equisetaceae) extracts," Journal of Medicinal Food, vol. 18, no. 7, pp. 830-834, 2015.

[62] M. Jin, C. Zhang, T. Zheng et al., "A new phenyl glycoside from the aerial parts ofEquisetum hyemale," Natural Product Research, vol. 28, no. 21, pp. 1813-1818, 2014.

[63] H. Wiedenfeld, A. Andrade Cetto, and C. Perez Amador, "Flavonol glycosides from Equisetum myriochaetum," Biochemical Systematics and Ecology, vol. 28, no. 4, pp. 395-397, 2000.

[64] M. R. Camacho, D. Chavez, R. Mata et al., "Chemical Studies on Mexican Plants used in Traditional Medicine XXII: constituents of Equisetum myriochaetum Schlecht. et Cham," Fitoterapia, vol. 63, no. 5, pp. 471-472, 1992.

[65] Z. Wei, Y. Pan, L. Li et al., "Simultaneous determination of phenolic compounds inEquisetum palustreL. by ultra high performance liquid chromatography with tandem mass spectrometry combined with matrix solid-phase dispersion extraction," Journal of Separation Science, vol. 37, no. 21, pp. 3045-3051, 2014.

[66] A. Andrade Cetto, H. Wiedenfeld, M. C. Revilla, and I. A. Sergio, "Hypoglycemic effect of Equisetum myriochaetum aerial parts on streptozotocin diabetic rats," Journal of Ethnopharmacology, vol. 72, no. 1-2, pp. 129-133, 2000.

[67] H. Zhang, N. Li, K. Li, and P. Li, "Effect of ethanol root extract of equisetum arvense (L) on urinary bladder activity in rats and analysis of principal plant constituents," Tropical Journal of Pharmaceutical Research, vol. 14, no. 8, pp. 1451-1458, 2015.

[68] A. Gažová, S. Valášková, V. Žufková et al., "Clinical study of effectiveness and safety of CELcomplex ${ }^{\circledR}$ containing cucurbita pepo seed extract and flax and casuarina on stress urinary incontinence in women," Journal of Traditional and Complementary Medicine, vol. 9, no. 2, pp. 138-142, 2019.

[69] S. Perna, M. Biserni, F. Borsani, M. Berardi, D. Spadaccini, and M. Rondanelli, "Effect of a mixture of botanicals extracts plus mannitol on hydration and bloating sensation. An open label study in women with high extra cellular water," Natural Product Research, vol. 34, no. 17, pp. 2500-2504, 2020.

[70] A. Crescenti, F. Puiggròs, A. Colomé et al., "Antiurolithiasic effect of a plant mixture of herniaria glabra, agropyron repens, equisetum arvense and sambucus nigra (herbensurina ${ }^{\circledR}$ ) in the prevention of experimentally induced nephrolithiasis in rats," Arch Esp Urol, vol. 68, no. 10, pp. 739-749, 2015.

[71] T. Boeing, L. M. da Silva, M. Mariott, S. F. d. Andrade, and P. de Souza, "Diuretic and natriuretic effect of luteolin in normotensive and hypertensive rats: role of muscarinic acetylcholine receptors," Pharmacological Reports, vol. 69, no. 6, pp. 1121-1124, 2017.

[72] A. Gasparotto Junior, T. B. L. Prando, T. D. S. V. Leme et al., "Mechanisms underlying the diuretic effects of Tropaeolum majus L. extracts and its main component isoquercitrin," Journal of Ethnopharmacology, vol. 141, no. 1, pp. 501-509, 2012.

[73] S. S. Bachhav, S. D. Patil, M. S. Bhutada, and S. J. Surana, "Oleanolic acid prevents glucocorticoid-induced hypertension in rats," Phytotherapy Research, vol. 25, no. 10, pp. 1435-1439, 2011.

[74] J. H. Burn, "Antidiuretic effect of nicotine and its implications," Bmj, vol. 2, no. 4725, pp. 199-201, 1951.

[75] R. M. Férez Gutiérrez, G. Yescas Laguna, and A. Walkowski, "Diuretic activity of Mexican equisetum," Journal of Ethnopharmacology, vol. 14, no. 2-3, pp. 269-272, 1985.

[76] F. Schlickmann, T. Boeing, L. N. B. Mariano et al., "Gallic acid, a phenolic compound isolated from mimosa bimucronata (DC.) Kuntze leaves, induces diuresis and saluresis in rats," Naunyn-Schmiedeberg's Archives of Pharmacology, vol. 391, no. 6, pp. 649-655, 2018.

[77] J. C. Moser, C. C. Cechinel-Zanchett, L. N. B. Mariano, T. Boeing, L. M. Da Silva, and P. de Souza, "Diuretic, natriuretic and $\mathrm{Ca} 2+$-sparing effects induced by rosmarinic and caffeic acids in rats," Revista Brasileira de Farmacognosia, vol. 30, no. 4, pp. 588-592, 2020.

[78] C. C. Cechinel-Zanchett, L. N. Bolda Mariano, T. Boeing et al., "Diuretic and renal protective effect of kaempferol 3O-Alpha-1-rhamnoside (afzelin) in normotensive and hypertensive rats," Journal of Natural Products, vol. 83, no. 6, pp. 1980-1989, 2020.

[79] S. Sanjeev, R. M. Bidanchi, M. K. Murthy, G. Gurusubramanian, and V. K. Roy, "Influence of ferulic acid consumption in ameliorating the cadmium-induced liver and renal oxidative damage in rats," Environmental Science and Pollution Research, vol. 26, no. 20, pp. 2063120653, 2019.

[80] S. Chowdhury, S. Ghosh, A. K. Das et al., "Ferulic acid protects hyperglycemia-induced kidney damage by regulating oxidative insult, inflammation and autophagy," Frontiers in Pharmacology, vol. 10, no. 1, 2019.

[81] S. M. Mir, H. G. Ravuri, R. K. Pradhan et al., "Ferulic acid protects lipopolysaccharide-induced acute kidney injury by suppressing inflammatory events and upregulating antioxidant defenses in Balb/c mice," Biomedicine \& Pharmacotherapy, vol. 100, pp. 304-315, 2018.

[82] A. M. Mahmoud, O. E. Hussein, S. M. Abd El-Twab, and W. G. Hozayen, "Ferulic acid protects against methotrexate nephrotoxicityviaactivation of $\mathrm{Nrf} / \mathrm{ARE} / \mathrm{HO}-1$ signaling and PPAR $\gamma$, and suppression of NF- $\kappa \mathrm{B} / \mathrm{NLRP} 3$ inflammasome axis," Food \& Function, vol. 10, no. 8, pp. 4593-4607, 2019.

[83] M. A. Alam, C. Sernia, and L. Brown, "Ferulic acid improves cardiovascular and kidney structure and function in hypertensive rats," Journal of Cardiovascular Pharmacology, vol. 61, no. 3, pp. 240-249, 2013.

[84] F. H. M. Do Monte, J. G. Dos Santos, M. Russi, V. M. N. Bispo Lanziotti, L. K. A. M. Leal, and G. M. De Andrade Cunha, "Antinociceptive and anti-inflammatory properties of the hydroalcoholic extract of stems from equisetum arvense L. in mice," Pharmacological Research, vol. 49, no. 3, pp. 239-243, 2004.

[85] C. Steinborn, O. Potterat, U. Meyer et al., "In vitro antiinflammatory effects of equisetum arvense are not solely mediated by silica," Planta Medica, vol. 84, no. 08, pp. 519-526, 2018.

[86] R. Hedaya, "Five herbs plus thiamine reduce pain and improve functional mobility in patients with pain: a pilot 
study," Alternative Therapies in Health and Medicine, vol. 23, no. 1, pp. 14-19, 2017.

[87] D. D. Cetojević-Simin, J. M. Canadanović-Brunet, G. M. Bogdanović et al., "Antioxidative and antiproliferative activities of different horsetail (Equisetum arvense L.) extracts," Journal of Medicinal Food, vol. 13, no. 2, pp. 452-459, 2010.

[88] V. Alexandru, D. Petrusca, and E. Gille, "Investigation of pro-apoptotic activity of Equisetum arvense L. water extract on human leukemia U 937 cells," Romanian Biotechnological Letters, vol. 12, no. 2, pp. 3139-3147, 2007.

[89] H. I. Al Mohammed, B. A. Paray, and I. A. Rather, "Anticancer activity of EA1 extracted from equisetum arvense," Pakistan Journal of Pharmaceutical Sciences, vol. 30, no. 5, pp. 1947-1950, 2017.

[90] A. A. Bhat, B. Ahamad, M. U. Rehman, and P. Ahmad, "Impact of ethanolic extract of equisetum arvense (EA1) on pancreatic carcinoma AsPC-1 cells," Saudi Journal of Biological Sciences, vol. 27, no. 5, pp. 1260-1264, 2020.

[91] N. Radulović, G. Stojanović, and R. Palić, "Composition and antimicrobial activity of equisetum arvense L. essential oil," Phytotherapy Research, vol. 20, no. 1, pp. 85-88, 2006.

[92] S. Badole and S. Kotwal, "Equisetum arvense: ethanopharmacological and phytochemical review with reference to osteoporosis," The International Journal of Pharmaceuticals Sciences and Health Care, vol. 1, no. 4, pp. 2249-5738, 2014.

[93] F. Mojab, M. Kamalinejad, and H. R. Vahidipour, "Phytochemical screening of some species of Iranian plants," Iranian Journal of Pharmaceutical Research, vol. 2, no. 2, pp. 77-82, 2003.

[94] C. Bessa Pereira, P. S. Gomes, J. Costa-Rodrigues et al., "Equisetum arvense hydromethanolic extracts in bone tissue regeneration: in vitro osteoblastic modulation and antibacterial activity," Cell Proliferation, vol. 45, no. 4, pp. 386-396, 2012.

[95] S. Kotwal and S. Badole, "Anabolic therapy with Equisetum arvense along with bone mineralising nutrients in ovariectomized rat model of osteoporosis," Indian Journal of Pharmacology, vol. 48, no. 3, pp. 312-315, 2016.

[96] N. Arbabzadegan, A. A. Moghadamnia, S. Kazemi et al., "Effect of equisetum arvense extract on bone mineral density in wistar rats via digital radiography," Caspian Journal of Internal Medicine, vol. 10, no. 2, pp. 176-182, 2019.

[97] G. T. Vieira, T. T. De Oliveira, M. A. A. Carneiro et al., "Antidiabetic effect of Equisetum giganteum L. extract on alloxan-diabetic rabbit," Journal of Ethnopharmacology, vol. 260, 2020.

[98] R. A. Da Silva, L. P. Bernardo, J. M. L. Moreno, V. S. Lara, and V. C. Porto, "Equisetum giganteum influences the ability of candida albicans in forming biofilms over the denture acrylic resin surface," Pharmaceutical Biology, vol. 55, no. 1, pp. 1698-1702, 2017.

[99] M. C. Revilla, A. Andrade-Cetto, S. Islas, and H. Wiedenfeld, "Hypoglycemic effect of Equisetum myriochaetum aerial parts on type 2 diabetic patients," Journal of Ethnopharmacology, vol. 81, no. 1, pp. 117-120, 2002.

[100] C. F. Dos Santos Alves, P. C. Bonez, M. D. E. De Souza et al., "Antimicrobial, antitrypanosomal and antibiofilm activity of Equisetum hyemale," Microbial Pathogenesis, vol. 101, pp. 119-125, 2016.

[101] T. Nagai, T. Myoda, and T. Nagashima, "Antioxidative activities of water extract and ethanol extract from field horsetail (Tsukushi) Equisetum arvense L.," Food Chemistry, vol. 91, no. 3, pp. 389-394, 2005.
[102] D. Stajner, B. M. Popović, J. Canadanović-Brunet, and P Boza, "Free radical scavenging activity of three Equisetum species from Fruska gora mountain," Fitoterapia, vol. 77, no. 7-8, pp. 601-604, 2006.

[103] J. G. Dos Santos Jr, M. M. Blanco, F. H. M. Do Monte et al., "Sedative and anticonvulsant effects of hydroalcoholic extract of Equisetum arvense," Fitoterapia, vol. 76, no. 6, pp. 508-513, 2005.

[104] N. Singh, S. Kaur, P. M. Bedi, and D. Kaur, "Anxiolytic effects of Equisetum arvense Linn. extracts in mice," Indian Journal of Experimental Biology, vol. 49, no. 5, pp. 352-356, 2011. 